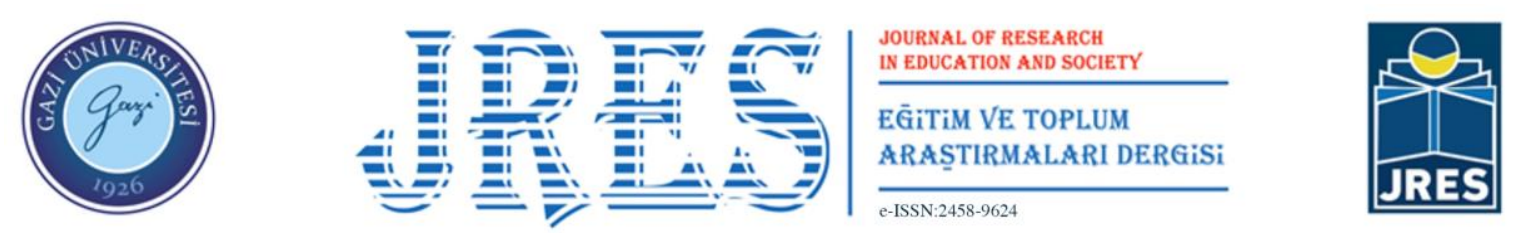

Cilt: 8 Sayı: 2 Sayfa Aralığı: 378-398 e-ISSN: 2458-9624 DOI: 10.51725/etad.905167

\title{
Lise Öğrencilerinin Siber Zorbalık ve Siber Mağduriyet Durumları ile Yalnızlık Algıları Arasındaki İlişkinin İncelenmesi*
}

\author{
Investigation of the Relationship between High School Students' \\ Cyberbullying and Cyber Victimization Situations and Their Perceptions of
}

Loneliness

\section{Mehmet İbrahim Talan, Gülnihal Bostan, Yağmur Öztürk}

\section{ÖZ}

İnternete erişimin yaygınlaşmasıyla birlikte siber zorbalık ve siber mağduriyet durumlarıyla sıkça karşılaşılmaktadır. Bu durumlar ergenlik döneminde yalnızlık algısı, depresyon ve intihar gibi ciddi sonuçları doğurabilir. Çalışmanın amacı ergenlerde karşılaşılan siber zorbalık ve mağduriyet durumları ile yalnızlık algısı arasındaki ilişkinin ve bu ilişkiye etki eden faktörlerin araştırılmasıdır. Çalışma, ilişkisel tarama modelinin kullanıldığı betimleyici bir çalışmadır. Veri toplama araçları olarak UCLA Yalnızlık Ölçeği, Siber Zorbalık Ölçeği, Siber Mağduriyet Ölçeği ve kişisel bilgi formu kullanılmıştır. Ölçekler ve bilgi formu bir meslek lisesindeki 262 öğrenciye uygulanmıştır. Verilerin analizinde; bağımsız örneklem $t$ testi, tek yönlü varyans analizi, GamesHowell analizi ve Pearson Korelasyon analizi yöntemleri kullanılmıştır. Çalışma sonucunda yalnızlık algısı ile siber zorbalık arasında ve siber zorbalık ile siber mağduriyet arasında pozitif yönde ilişki bulunmuştur. Siber zorbalığın sınıf düzeyine, internete bağlanma süresine ve bağlanma amacına göre farklılık gösterdiği; siber mağduriyetin ise sinıf düzeyine, internete bağlanma süresine, ailenin aylık gelirine ve cep telefonunun türüne göre farkl1lık gösterdiği tespit edilmiştir.
Yazar Bilgileri

Mehmet İbrahim Talan

Öğretmen, Milli Eğitim

Bakanlığı, Ankara, Türkiye

m.ibrahimtalan@gmail.com

Gülnihal Bostan (iD

Bağımsız Araştırmacı,

Ankara, Türkiye

bostangulnihal@gmail.com

Yağmur Öztürk

Bağımsız Araştırmacı,

Ankara, Türkiye

yagmur.ozturkk.00@gmail.com

Makale Bilgileri

Anahtar Kelimeler

Sosyal medya

Siber zorbalık

Siber mağduriyet

Yalnızlık algısı

Keywords

Social media

Cyberbullying

Cyber victimization

Loneliness perception

Makale Geçmişi

Geliş: 29/03/2021

Düzeltme: 17/12/2021

Kabul: 17/12/2021 respect to class level, internet connection time, monthly income of the family and type of mobile phone.

uriyet durumları ile Atıf için: Talan, M. İ., Bostan, G. ve Öztürk, Y. (2021). Lise öğrencilerinin siber zorbalık ve siber mağduriye
yalnızlık algıları arasındaki ilişkinin incelenmesi. JRES, 8(2), 378-398. https://doi.org/10.51725/etad.905167 Etik Bildirim: Bu araştırma, 01.01.2020 tarihinden önce yapıldığından etik kurul kararı zorunluluğu yoktur. 


\section{Giriş}

Evlerde, iş yerlerinde veya internet kafelerde bilgisayarlar aracıllğ̆ ile erişim sağlanan internet, akıllı cep telefonlarının yaygınlaşmasıyla birlikte istenilen her an erişilebilir konuma gelmiştir. İnternet, hayatın günlük akışını kolaylaştıran ve bilgiye erişimi hızlandıran pek çok olumlu özelliği beraberinde getirdiği gibi bireylerin kullanım biçimine göre olumsuz sonuçlara da yol açabilmektedir. Dolandırıcılık, hırsızlık, tehdit ve zorbalık gibi suç teşkil eden davranışlar, gittikçe yaygınlaşan internet uygulamaları üzerinden de gerçekleştirilebilir durumdadır. Digital in 2017: Global Owerview (2017) araştırmasına göre dünyada internet kullananların sayısı 2016 yılına göre $\% 10$ artarak genel nüfusun \%50' sine ulaşmıştır. İnternet kullanıcıları içerisinde mobil internet üzerinden internete erişenlerin oranı \%46'dır (We Are Soical, 2017). Dünya nüfusunun \%37'si sosyal medyayı aktif olarak kullanmaktadır. Bu kullanıcıların \%34'ü ise sosyal medyayı cep telefonundan kullanmaktadırlar (We Are Soical, 2017). Türkiye'de evden internet erişimine sahip hane oranı 2017 yılında \%80,7'ye yükselmiştir (Türkiye İstatistik Kurumu [TÜIK], 2017).

Bireylerin internet kullanımları, bankacılık işlemleri, seyahat planlamaları, sağlık sistemleri ve eğlence içeriklerine ulaşım gibi farklı türde amaçlar için olsa da ağırlıklı olarak sosyal medya uygulamaları etrafında toplanmıştır. 2016 yılının ilk üç ayında internet kullanan bireylerin \%82,4'ü sosyal medya uygulamalarında profil oluşturma, mesaj gönderme ve fotoğraf paylaşma gibi işlemler yapmışlardır (TÜIK, 2016). Aktif sosyal medya kullanım oranının \%60 olduğu Türkiye'de, kullanıcıların günlük 3 saatlik süreyi sosyal medyaya ayırdıkları tespit edilmiştir. Türkiye 48 milyon üye sayısı ile Facebook üye sayısı sıralamasında dünya genelinde 7. sıradadır. Cep telefonları üzerinden sosyal medya uygulamalarını kullananların dünya ortalaması \%34 iken Türkiye'de bu oran \%52'dir (We Are Soical, 2017).

İnternet ve cep telefonu kullanımı küçük yaş gruplarına kadar inmiştir. Türkiye' de 6-10 yaş aralığındaki grup içerisinde internet kullanmaya başlama yaşı ortalama 6, cep telefonu kullanmaya başlama yaşı ise 10 olarak tespit edilmiştir. Çocukların interneti \%79,5 oranında oyun oynama, \%56,7 oranında bilgi arama amacıyla ve \%53,5 oranı ile de sosyal medya uygulamaları için kullandıkları görülmüştür. Çocukların \%38,2'si her gün iki saate kadar, \%47,4'ü ise üç ile on saat arasında interneti aktif olarak kullanmaktadır (TÜİK, 2013).

Araştırmalara göre dünya genelinde ve ülkemizde internet kullanımı, internette geçirilen süre ve sosyal medya uygulamalarına ayrılan vakit giderek artmaktadır (TÜİK, 2013; We Are Soical, 2017). İnternetin ve sosyal medyanın yaygınlaşması sonucu bu uygulamalara erişimi olan kullanıcılar arasında etkileşim ortaya çıkmaktadır. Ortaya çıkan bu etkileşimin bireylerin benlik gelişimlerine ve sosyokültürel özelliklerine olumlu etkileri olduğu kadar olumsuz etkileri de olabilmektedir. Kültürler arası aktarıma imkân tanıyan ve bilgiye ulaşmayı kolaylaştıran internetin, kötü niyetli veya sorunlu kullanımı sonucunda bireyler üzerinde iyi olma halini olumsuz etkileyen durumlar ortaya çıkabilir. Bu olumsuz durumların başında siber zorbalık ve siber mağduriyet gelmektedir.

Zorbalık kavramı Türk Dil Kurumu (2011) tarafından "gücüne güvenerek hükmü altında bulunanlara söz hakkı ve davranış özgürlüğü tanımayan (kimse), müstebit” olarak tanımlanmıştır. Siber zorbalık, literatürde bilgi ve iletişim teknolojilerini kullanmak suretiyle özel veya tüzel kişiliklere ya da bir gruba karşı yapılan ilişkisel veya teknik anlamda zarar verme davranışları olarak tanımlanmıştır (Arıcak'tan aktaran Ayas ve Horzum, 2010). Bir başka tanımda ise siber zorbalık, bilişim teknolojileri cihazları kullanılarak zarar vermek amacıyla kasten ve tekrarlayıcı bir şekilde gösterilen düşmanca davranışlar olarak tanımlanmıştır (Patchin ve Hinduja, 2006). Tanımların ortak noktası, siber 
zorbalık olarak nitelendirilen davranışların kasıtlı yapılması, tekrarlı olması ve bu davranışların bilişim araçları kullanılarak gerçekleştirilmesidir (Peker, 2015; Peker, Özhan ve Eroğlu, 2015).

Siber zorbalığı genel zorbalıktan ayıran üç temel nokta; zorba davranış gösteren bireyin anonim kimliğe sahip olabilmesi, siber zorbalığın internet aracılığıyla çok geniş coğrafyalara hızla yayılabilmesi ve cinselliğin daha kolay ve yoğun kullanılabilmesi gösterilebilir (Ayas ve Horzum, 2010).

Siber zorbalık iki türde karşımıza çıkmaktadır. Bunlardan ilki bilişim uygulama ve alt yapılarına karşı düzenlenen zorbalıktır. Diğer siber zorbalık türü ise bilişim teknolojilerini kullanarak kişilere, kurumlara veya bir gruba hakaret etmek, lakap takmak, grup içerisinden bir kişiyi hedef göstererek dışlanmasını sağlamak, kişiler arası özel içerikleri rıza dışı yayınlamak ve cinsel içerikli tehdit mesajları göndermek gibi eylemleri içeren elektronik iletişim zorbalığıdır (Gezgin ve Çuhadar, 2012; Tanrıkulu, Kınay ve Arıcak, 2013; Yenilmez ve Seferoğlu, 2013).

Okul çağındaki bireylerde karşılaşılan okul zorbalığının ders saatleri ve okul ortamı ile sınırlı kalmadığı, dijital teknolojiler ve internetin yaygınlaşması ile okuldan sonra da siber zorbalık biçiminde devam ettiği söylenebilir. Okul zorbalığının özellikleri ile siber zorbalığın özellikleri karşılaştırıldığında fiziksel eylemler dışındaki diğer unsurların ortak olduğu görülebilir. Kanada'da ortaokul öğrencileri üzerinde yapılan bir çalışmada mağdurların \%31,8'i, okul arkadaşları tarafından siber zorbalığa maruz kaldıklarını belirtmişlerdir (Li, 2005). Zorbalık sadece fiili şiddet içeren davranışlar barındırmaz. Zorbalığın ayırt edici özellikleri; bilinçli ve tekrarlı olması, mağdura fiziksel veya psikolojik olarak zarar verme amacı taşıması ve mağdurun kendisini bu saldırılardan koruyamayacak durumda olmasıdır (Pişkin, 2002). Pişkin (2002), okul zorbalığını öğrencilerin kendilerinden daha güçsüz buldukları diğer öğrencileri sürekli ve kasıtlı olarak rahatsız etmeleriyle sonuçlanan bir saldırganlık türü olarak tanımlamıştır.

Siber zorbalar, geleneksel zorbalıkta olduğu gibi kendilerinden daha güçsüz gördükleri bireyleri kurban seçerler. Geleneksel zorbalıkta güç, zorbanın fiziksel ya da sosyal olarak üstün olması olarak nitelendirilirken, siber zorbalıkta ise bilişim cihazlarını ve internet uygulamalarını etkin kullanabilmek güç olarak nitelendirilebilir (Patchin ve Hinduja, 2006). Geleneksel zorbalığa maruz kalan öğrenciler ile zorba davranışlar gösterenlerin, genellikle siber zorba ve siber mağdur rollerindeki aynı kişiler olduğu görülmüştür (Akça, 2016). Siber zorbalık, yüz yüze ifade edilemeyecek sözlerin söylenmesinde veya yüz yüze yapılamayacak davranışların aktarılmasında bir araç olarak kullanılabilir (Kowalski ve Limber, 2013).

İnternet, cep telefonu, sosyal medya uygulamalarının yaygınlaşması ve kullanıcıların ağırlıklı olarak okul çağındaki yaş grubu bireyler olması sebebiyle okul problemlerinde siber zorbalık olayları giderek artış göstermektedir (Ayas ve Horzum, 2012; Li, 2006).

Araştırmalarda, siber zorbalık olarak nitelendirilen davranışların mağdur ve zorba arasındaki arkadaşlık ilişkisinin bozulmasıyla ortaya çıkan intikam duygusunun bir sonucu olduğu gibi (Özdemir ve Akar, 2011), güç gösterisi sergileme (Patchin ve Hinduja, 2006), psikolojik bozukluklar, yalnızlık, iletişim ve ilişkileri yürütememe, depresyon gibi nedenlerle de ortaya çıktığı görülmüştür (Kim, LaRose ve Peng, 2009).

Siber zorbalık gençlerde öfke, intikam ve değersiz hissetme gibi olumsuz duyguların ortaya çıkmasına sebep olabilir. Bu olumsuz duygu ve düşünceler bireyin kendisine ve topluma karşı daha kolay yabancılaşmasına yol açar (Şahin, Sarı, Özer ve Er, 2010). Yabancılaşma kavramı içerisinde yer alan yalıtılmışlık ve güçsüzlük duygusu arttıkça bireyin hissettiği yalnızlık duygusu da artmaktadır (Atli, Keldal ve Sonar, 2015). Literatürde yalnızlık üzerine yapılan çalışmalar, yalnızlı̆̆ı istenilmeyen, 
kaçınılan, kaygı, öfke, üzüntü ve stres gibi olumsuz duygularla ilişkili bir yaşantı olarak tanımlamıştır. Yalnızlık, bireylerin topluma uyumunu zorlaştıran ve topluma karşı güvensizlik algısını geliştiren, istenilen kişilerle ilişki kurmada bireyin yetersiz hissetmesiyle ortaya çıkan bir durum olarak belirtilmiştir (Bahar ve Meral, 2016; Doğan, Çetin ve Sungur, 2009).

Yalnızlık, çocukluktan yetişkinliğe geçiş süreci olarak tanımlanan ergenlik döneminde diğer dönemlere göre daha yoğun hissedilir (Hartog'dan aktaran Kılınç ve Sevim, 2005). Sonuçları bakımından yüksek risk teşkil eden ergen yalnızlığının; intihar (Brown'dan aktaran Kılınç ve Sevim, 2005), depresyon, düşük benlik saygısı (Hudson, Elek ve Campbell-Grossman, 2000), suçluluk, evden kaçma, okul devamsızlığında artış ve okul başarısında düşüklük (Brennan'dan aktaran Esen, 2010) gibi ciddi problemlerle ilişkili olduğu yapılan çalışmalarda tespit edilmiştir.

Ergen yalnızlığı üzerine yapılan çalışmalar göstermiştir ki ergenlerin yalnızlıktan şikâyet ettikleri durum, aile içindeki yalnızlıktan daha çok arkadaş çevresindeki sosyal ilişkilerde yaşanan memnuniyetsizlik ve uyum problemlerinden kaynaklanmaktadır. Dolayısıyla ergenler için arkadaşlık ve akran ilişkileri, eksikliği durumunda yüksek risk taşıyan sonuçlar nedeniyle büyük önem arz etmektedir (Esen, 2010; Kılınç ve Sevim, 2005).

Siber zorbalık davranışı gösteren veya bu davranışa maruz kalan bireylerin okul başarıları düşmekte, okul devamsızlıklarında artış görülmektedir. Depresyon, öfke, intikam, anksiyete, korku, paranoya, üzüntü, yalnızlık gibi olumsuz duygu ve düşüncelere kapılan mağdurlarda maruz kaldıkları siber zorbalığın şiddetine göre intihar girişiminde bulunma gibi daha ağır tablolar görülebilir (Serin, 2012). Yıkıcı sonuçları olabilen siber zorbalık, mağdur üzerinde yaşamı boyunca taşıyacağı izler bırakabilmekte ve toplumsal ilişkileri olumsuz yönde etkilemektedir (Gezgin ve Çuhadar, 2012).

Literatürdeki benzer çalışmalar incelendiğinde siber zorbalık ve siber mağduriyet, birlikte ele alındığı gibi ayrı ayrı da ele alınmışlardır. Siber zorbalık ve siber mağduriyet durumları literatürde ağırlıklı olarak cinsiyet, yaş, eğitim durumu, internet kullanım amacı, internet bağımlılığı ve sınıf düzeyi gibi bağımsız değişkenlerle olan ilişkileri bakımından araştııılmıştır (Ayas ve Horzum, 2012; Kavuk ve Keser, 2016; Semerci, 2017).

Ortaöğretim öğrencileri üzerinde siber zorbalık ve saldırganlık arasındaki ilişkiyi inceleyen Peker (2015), dolaylı ve fiziksel saldırganlık puanlarının siber zorbalığı anlamlı düzeyde yordadığı bulgusuna ulaşmıştır. Gencer (2017), 7. ve 8. sınıf öğrencilerinden oluşan 779 birey üzerinde yaptığ1 araştırma sonucunda siber zorbalık davranışı ile sınıf düzeyi, cinsiyet, evde kullanılabilecek bilgisayar olup olmaması ve interneti kullanım yeri değişkenleri arasında anlamlı bir ilişkinin olduğu sonuçlarına ulaşmıştır. İnternet bağımlılığı ile siber zorbalık arasında ise orta düzeyde pozitif bir ilişki olduğu görülmüştür (Gencer, 2017).

Semerci (2017) de, 12. sınıf öğrencilerinin en fazla siber zorbalık davranışında bulunan ve siber zorbalığa en fazla maruz kalan grup olduğunu tespit etmiştir. Aynı çalışmada 9.sınıf öğrencilerinin ise en az siber zorbalık davranışında bulunan ve en az siber zorbalığa maruz kalan grup olduğu tespit edilmiştir. Yaman ve Sönmez (2015), örneklemini 300 lise öğrencisinin oluşturduğu çalışmalarında, erkek öğrencilerin kız öğrencilere göre daha fazla siber zorbalık davranışında bulunduklarını; sınıf düzeyinde ise öğrenciler arasında anlamlı bir farklılık olmadığını tespit etmişlerdir.

İnternet tabanlı oyunlar ve sosyal medya uygulamalarında geçirilen süre, siber zorbalığın çevrimiçi uygulamalar üzerinden gerçekleştirildiği göz önüne alındığında siber zorbalık ve siber mağduriyet üzerinde etkili olabilir. Bireylerin ekonomik durumları, bilişim teknolojileri cihazlarına erişimleri noktasında önemli bir etkendir. Eroğlu, Aktepe, Akbaba, Işık ve Özkorumak (2015), 
Süleyman Demirel Üniversitesi Tıp Fakültesi Çocuk ve Ergen Psikiyatrisi polikliniğine başvuran 160 ergenle yürüttüğü çalışma sonucunda siber zorbalığın; sosyal paylaşım sitelerinde günlük geçirilen süre, internet bağımlılığı riski, interneti en sık çevrimiçi oyun oynamak amacıyla kullanma ve ailenin aylık geliri ile ilişkili olduğunu göstermiştir. Aynı çalışmada siber mağduriyetin ise internet kafeye gitme sıklığı, internet bağımlılı̆̆ riski ve interneti en çok çevrimiçi oyun oynamak amacıyla kullanmayla ilişkili olduğu görülmüştür. Ergenin, annesinin internet becerisi hakkındaki algısı ile siber zorbalık ve mağduriyet arasında da anlamlı bir ilişki olduğu görülmüştür. Annesinin internet kullanma becerisini kendisine göre daha kötü olarak niteleyen ergenlerin siber zorbalık ve siber mağduriyet puan ortalamaları, diğer gruplara göre daha yüksek çıkmıştır (Eroğlu vd., 2015).

Akça (2016), 516 lise öğrencisi üzerinde yürüttüğü çalışmada yabancı kişilerle mesajlaşan veya görüntülü görüşme yapan, gizli numaradan gelen aramalara cevap veren ve cep telefonuna şifre koyan öğrencilerin siber mağduriyet puanlarının diğer öğrencilere göre daha yüksek olduğunu belirlemiştir. Ayrıca aynı çalışmada siber mağduriyet puanları ile benlik saygısı puanları arasında negatif yönde bir korelasyon olduğu görülmüştür.

Özel (2013), örneklemini 1324 lise öğrencisinin oluşturduğu çalışmasında siber zorbalık ve siber mağduriyet ile depresyon ve benlik saygısı ilişkisini incelemiştir. Depresyon düzeyinin siber zorbalıktaki pozitif yöndeki artışı açıkladığının tespit edildiği çalışmada, benlik saygısının azalmasının ise siber mağduriyetteki artışı anlamlı düzeyde açıkladığı görülmüştür. Haskan-Avcı ve Yıldırım (2014), 899 lise öğrencisi üzerinde yaptı̆̆ı çalışmada yüksek şiddet eğilimi gösteren öğrencilerin yalnızlık düzeylerinin yüksek olduğunu, aile, arkadaş ve öğretmen desteklerinin ise düşük olduğunu tespit etmişlerdir (Haskan-Avcı ve Yıldırım, 2014).

Siber zorbalık, siber mağduriyet ve yalnızlık durumlarının ortak noktasının; ergenler üzerinde intihar, fiziksel hastalıklar, depresyon, akademik başarısızlık gibi ciddi sonuçlara yol açabilmesi olduğu söylenebilir (Gezgin ve Çuhadar, 2012; Haskan-Avcı ve Yıldırım, 2014; Kavuk ve Keser, 2016; Özel, 2013; Peker, 2015; Semerci, 2017). Siber zorbalığa maruz kalan bireylerin yalnızlaşması sonucu bireyler intikam gibi duygularla hareket ederek siber zorbalık davranışları gösterebilir (Akça, 2016; Gezgin ve Çuhadar, 2012; Semerci, 2017).

Siber zorbalık ile ilgili çalışmaların ülkemizde artan internet kullanımına paralel olarak yeteri kadar artış göstermediği söylenebilir (Ayas ve Horzum, 2012; Kavuk ve Keser, 2016). Ülkemizde yapılan çalışmaların ağırlıklı olarak siber zorbalık ve siber mağduriyetin sosyodemografik değişkenlerle olan ilişkisinin incelenmesiyle sınırlı kaldığı görülmüştür. Ergenlerde yalnızlık algısı ile internet bağımlılığı arasındaki ilişkiyi ortaya koyan çalışmaların yanında internet bağımlılığı ile siber zorbalık ve mağduriyet arasındaki ilişkiyi ortaya koyan çalışmalar da mevcuttur (Bahar ve Meral, 2016; Eroğlu vd., 2015; Esen, 2010; Gencer, 2017; Kavuk ve Keser, 2016). Buna rağmen literatürde yalnızlık algısı, siber zorbalık ve siber mağduriyet durumlarını birlikte inceleyen araştırmaların ise yok denecek kadar az olduğu görülmüştür. Siber zorbalık, siber mağduriyet ve yalnızlık algısı ergenlerde bir arada görülebilir. Böyle bir durum bireyde telafisi zor izler bırakabilir. Bu çalışmada siber zorbalık, siber mağduriyet ve yalnızlık algısı birlikte ele alınmıştır. Ergenlerde yalnızlık algısı ile siber zorbalık ve siber mağduriyet arasındaki ilişkinin ve bu ilişkiye etki eden faktörlerin incelenmesi bu çalışmanın ana amacını oluşturmaktadır. Çalışmada aşağıdaki sorulara yanıt aranmıştır:

- Ergenlerde yalnızlık algısı ile siber zorbalık arasında anlamlı bir ilişki var mıdır?

- Ergenlerde yalnızlık algısı ile siber mağduriyet arasında anlamlı bir ilişki var mıdır?

- Ergenlerde siber zorbalık ile siber mağduriyet arasında anlamlı bir ilişki var mıdır? 
- Ergenlerin cinsiyetine, ebeveynlerinin birliktelik durumuna, ergenlerin kardeşinin olup olmamasına, anne babalarının eğitim seviyesine ve ailelerinin aylık gelir durumuna göre oluşan gruplarda siber zorbalık, siber mağduriyet ve yalnızlık algısı anlamlı yönde farklılaşmakta midır?

- Ergenlerin sınıf tekrarı yapıp yapmamalarına, eğitim aldıkları sınıf seviyesine ve eğitim gördükleri mesleki bölüme göre oluşan gruplarda siber zorbalık, siber mağduriyet ve yalnızlık algısı anlamlı yönde farklılaşmakta mıdır?

- Ergenlerin akıllı telefon sahibi olup olmadıklarına, internet kullanma amaçlarına, internet kullanım sürelerine, internete nereden bağlandıklarına, sosyal medya kullanıp kullanmamalarına ve sosyal medyayı kullanma amaçlarına göre oluşan gruplarda siber zorbalık, siber mağduriyet ve yalnızlık algısı anlamlı yönde farklılaşmakta mıdır?

\section{Yöntem}

\section{Araştırma Modeli}

Çalışmanın araştırma modeli belirlenmeden önce literatürde benzer çalışmaların araştırma modelleri ve desenleri incelenmiştir. Nicel araştırma yöntemleri, olay ya da durumun betimlenmesine, ilişki ve farkların bulunmasına ve evreni temsil eden örneklem üzerinde hipotezlerin test edilmesine olanak tanır (Başol, 2008). Bu çalışmada ergenlerin yalnızlık algıları ile siber zorbalık ve siber mağduriyet seviyelerinin ortaya konulması ve çalışmaya konu bağımsız değişkenlere göre oluşan gruplarda bağımlı değişkenler yönünden anlamlı bir ilişkinin olup olmadığının belirlenmesi amaçlanmıştır. Araştırmada siber zorbalık, siber mağduriyet ve yalnızlık algısı arasındaki ilişkinin incelenmesi sebebiyle ilişkisel tarama modeli kullanılmıştır. İlişkisel tarama modeli iki ve daha çok değişken arasında birlikte değişimin varlığını ve derecesini belirlemeyi amaçlayan bir araştırma modelidir (Karasar'dan aktaran Semerci, 2017). Araştırma bu sebeple ilişkisel tarama modelinin kullanıldığı betimleyici bir çalışmadır.

\section{Çalışma Grubu}

$\mathrm{Bu}$ araştırmanın çalışma grubunu Ankara il merkezinde yer alan bir mesleki ve teknik anadolu lisesindeki 9, 10 ve 11.sınıflardan rastgele yöntemle seçilmiş 262 öğrenci oluşturmaktadır. Lise 9. sınıf öğrencileri herhangi bir meslek alanında yer almazken, 10. ve 11. sınıf öğrencileri ise bilişim teknolojileri, elektrik - elektronik teknolojileri, biyomedikal cihaz teknolojileri, makine teknolojileri, metal teknolojileri ve mobilya- iç mekân tasarımı bölümlerinden birinde eğitim görmektedirler. Son sınıf öğrencileri, üniversite ve kamu sınavlarına hazırlanmaları, yüksek seviyede gelecek kaygıları ve okul devamsızlıklarının staj sebebiyle artmasından dolayı çalışma grubundan çıkarılmıştır.

Çalışma grubu, araştırma modelinin hipotezlerin bir örneklem üzerinde sınanmasına ve sonuçların genellenebilirliğine imkân tanıması ile zaman ve maliyet kısıtlarından dolayı 9., 10. ve 11.sınıflarda eğitim gören tüm öğrencileri kapsamak yerine bir örneklem olarak oluşturulmuştur. Örneklem oluşturmada en önemli nokta çalışma evreninin en iyi şekilde temsil edilmesidir. Dolayısıyla örneklem sayısının hem evreni en iyi şekilde temsil edecek hem de boyutunun büyüklüğüyle zaman ve maliyet sınırına takılmayacak düzeyde olması beklenir. Literatürde evren sayısı bilinen çalışmalarda örneklem boyutunu hesaplamak için farklı metotlar kullanılmıştır. Bu çalışmada örneklem boyutu Eşitlik 1'de verilen eşitliğe göre hesaplanmıştır (Baş, 2013; Kılınç, 2012). 
$n=\frac{N \cdot t^{2} \cdot p \cdot q}{d^{2} \cdot(N-1)+t^{2} \cdot p \cdot q}$

N: Evren Sayıs1 = 1099

p: Görülme Sıklı̆̆

q: Görülmeme Sıklığ $(1-p)=0.7$

d: Örneklem Hatası $=0.05$

t(sd): Kabul edilen anlamlılık düzeyi hata düzeyi = 1.96

Çalışma evreni 9, 10 ve 11.sınıf öğrencilerinden oluşmakta olup toplamda 1099 öğrencidir. Görülme sıklı̆̆ı (p) değerinin belirlenmesinde literatürde siber zorbalık ve siber mağduriyet üzerine yapılan çalışmalar incelenmiş, siber zorbalık ve siber mağduriyetin görülme oranının \%18 ile \%30 arasında değiştiği görülmüştür (Ayas ve Horzum, 2012; Baştürk-Akca, Sayımer ve Ergül, 2015; Özel, 2013). Bu sebeple Eşitlik 1'de p değeri 0,3 olarak kabul edilmiştir. Bilimsel çalışmalarda anlamlılık değeri genellikle \%1 veya \%5 olarak seçilir (Baş, 2013). Literatürdeki benzer çalışmalar da dikkate alınarak anlamlılık düzeyi \%5 olarak belirlenmiştir. t değeri ise çalışmada kabul edilen 0,05 anlamlılık düzeyine göre 1,96 bulunmuştur. Bu değerler doğrultusunda örneklem büyüklüğü Eşitlik 1 ile hesaplanarak 254 olarak belirlenmiştir.

Örnekleme yöntemi olarak evreni en iyi şekilde temsil edebilmek için tabakalı örneklem yöntemi kullanılmıştır. Bu amaçla her sınıf ve bölüm düzeyinde kız ve erkek öğrencilerin örneklem içindeki yüzdeleri hesaplanmıştır. Yüzdelerin ondalıklı sayılar olmasından dolayı elde edilen sonuçlar yukarı yuvarlanmış, örneklem büyüklüğü yuvarlamalar sonucunda 262 öğrenci olmuştur. Her bir tabaka içinde öğrenci seçimi, katılımcıların eşit şansa sahip olabilmesi için tesadüfi örneklem yöntemiyle ve gönüllülük esası doğrultusunda yapılmıştır.

\section{Veri Toplama Araçları}

Veri toplama araçları olarak kişisel bilgi formu, UCLA Yalnızlık Ölçeği, Siber Zorbalık Ölçeği ve Siber Mağduriyet Ölçeği kullanılmıştır.

\section{Kişisel Bilgi Formu}

Araştırmacılar tarafından literatürdeki benzer çalışmalar incelenerek geliştirilmiş olan kişisel bilgi formu, katılımcının sosyodemografik özellikleri ile internet kullanım alışkanlıkları (amaç ve süre), sosyal medya kullanım durumu ve sosyal medya kullanım amacı hakkında bilgi edinmeyi amaçlayan, çoktan seçmeli cevabı olan sorulardan oluşmaktadır. Formda 18 madde bulunmaktadır. Kişisel bilgi formu ile cinsiyet, anne babanın birliktelik durumu, anne babanın hayatta olup olmaması, kardeşin olup olmaması, anne babanın eğitim seviyesi ve ailenin aylık gelir durumu ile katılımcıların ailelerinin demografik özellikleri hakkında bilgi edinilmesi amaçlanmıştır. Katılımcıların eğitim seviyeleri de sınıf tekrarı yapıp yapmadıklarına, sınıf düzeylerine ve eğitim aldıkları meslek dallarına ilişkin sorular ile tespit edilmiştir. İnternet kullanım alışkanlıkları bölümünde ise katılımcıların interneti ve sosyal medyayı hangi amaç için ve ne kadar süre kullandıkları, akıllı cep telefonuna sahip olma durumları ile internet erişimini nereden gerçekleştirdiklerine ilişkin bilgileri elde etmek amaçlanmıştır.

\section{UCLA Yalnızlık Ölçeği}

Russell, Peplau ve Ferguson (aktaran Demir, 1989) tarafından bireyin algıladı̆̆ı yalnızlık düzeyini ölçmek için geliştirilmiştir. Ölçek, 10 adet düz ve 10 adet ters yönde kodlanmış toplam 20 
maddeden oluşur. 4'lü Likert yapısına sahip ölçekten alınabilecek puanlar 20 ile 80 arasında değişmektedir. Ölçekten alınan puanın yüksekliği yalnızlığın daha yoğun yaşandığını gösterir. Ülkemizde geçerlilik ve güvenilirlik çalışması Demir (1989) tarafından yapılan ölçeğin Cronbach Alpha katsayısı 0,96 olarak bulunmuştur. Bu çalışmada ise ölçeğin Cronbach Alpha katsayısı 0,772 olarak bulunmuştur.

\section{Siber Zorbalık Ölçeği}

Arıcak, Kınay ve Tanrıkulu (2012) tarafından geliştirilmiş Siber Zorbalık Ölçeği, dörtlü skala yapısına sahip 24 maddeden oluşmaktadır. Ölçekten alınabilecek puanlar 24 ile 96 arasında değişmektedir. Puanların yükselmesi siber zorbalık düzeyinin yüksekliğine işaret etmektedir. Arıcak vd., (2012) tarafından ölçeğin Cronbach Alpha katsayısı 0,95, test-tekrar test güvenilirlik katsayısı ise 0,70 olarak bulunmuştur. Bu çalışmada Cronbach Alpha katsayısı ise 0,96 olarak bulunmuştur.

\section{Siber Mağduriyet Ölçeği}

Arıcak vd. (2012) tarafından 11 ile 18 yaş arasındaki ergenler için geliştirilmiştir. "Evet" ve "Hayır" olmak üzere 2 yanıt içeren ölçek, 24 maddeden oluşmaktadır. Tersine madde içermeyen ölçekten alınabilecek puanlar 24 ile 48 arasında değişmektedir. Puanın yükselmesi siber mağduriyet düzeyinin yükselmesini gösterir. Ölçeğin Cronbach Alfa katsayısı 0,89, test-tekrar test güvenilirlik katsayısı ise 0,75 olarak bulunmuştur. Bu çalı̧̧mada ise Cronbach Alfa katsayısı ise 0,95 olarak bulunmuştur.

\section{Etik Bildirim}

Bu araştırma, 01.01.2020 tarihinden önce yapıldığından etik kurul kararı zorunluluğu yoktur.

\section{Verilerin Analizi}

Verilerin analizinde 262 katılımcının ölçeklere verdikleri yanıtlardan elde edilen veriler ${ }^{1}$ kullanılmıştır. İlk aşamada Siber Zorbalık Ölçeği, Siber Mağduriyet Ölçeği ve UCLA Yalnızlık Ölçeği'nin güvenilirlik analizleri, Cronbach Alpha yöntemi kullanılarak yapılmıştır. Analiz sonucunda üç ölçeğin güvenilirlik katsayıları 0,70'in üzerinde çıkmıştır. Bu değer sonucunda ölçeklerin güvenilir olduğu söylenebilir (Baykal, 2016).

Tablo 1'de çalışmanın bağımlı değişkenleri olan siber zorbalık, siber mağduriyet ve yalnızlık algısı ölçeklerinden alınan puanların basıklık ve çarpıklık değerleri verilmiştir.

Tablo 1. Bağımlı Değişkenlerin Çarpıklık ve Basıklık Değerleri

\begin{tabular}{ccc}
\hline Bağımlı Değişkenler & Çarpıklık (Skewness) & Basıklık (Kurtosis) \\
\hline Yalnızlık Algısı & 0,27 & $-0,939$ \\
\hline Siber Mağduriyet & 1,718 & 1,915 \\
\hline Siber Zorbalık & 1,463 & 0,877 \\
\hline
\end{tabular}

Grup karşılaştırmalarında parametrik yöntemlerin kullanılıp kullanılmayacağını belirlemek için, çalışmanın bağımlı değişkenlerini oluşturan verilerin normal dağılım durumları incelenmiştir. Kolmogorov-Smirnov ve Shapiro-Wilk analizlerine göre verilerin normal dağılım göstermedikleri görülmüştür $(p<0,05)$. Fakat literatürdeki benzer çalışmalarda çarpıklık ve basıklık değerlerinin -3 ile +3 arasında olması durumunda verilerin normal dağılım gösterdiği kabul edilmiştir (Fidell'den aktaran Peker, 2015). George ve Mallery (2010) ise verilerin basıklık ve çarpıklık değerlerinin -2,0 ile 2,0 arasında

\footnotetext{
${ }^{1}$ Araştırmaya katılan tüm katılımcıların ölçekte yer alan ifadelere doğru ve samimi cevap verdikleri varsayılmıştır.
} 
olması durumunda, verilerin normal dağılım gösterdiğinin kabul edilebilir olduğunu belirtmiştir. Bu sebeple bağımlı üç değişken için çarpıklık ve basıklık değerlerine bakılmıştır. Siber zorbalık puanlarının basıklık ve çarpıklık değerleri belirtilen sınırları aştığı için, kutu grafiği yardımıyla tespit edilen üç outlier veri çalışmadan çıkartılmıştır. Outlier dışlanmasından sonra basıklık ve çarpıklık değerlerinin belirtilen sınırlar içinde olduğu görülmüştür (bkz. Tablo 1). Bu sebeple verilerin normal dağılım gösterdiği kabul edilmiş ve verilerin analizinde parametrik yöntemler kullanılmıştır.

Kişisel bilgi formundan elde edilen sosyodemografik bilgiler ile internet kullanım alışkanlığını içeren bilgiler çalışmanın bağımsız değişkenleri iken yalnızlık algısı, siber zorbalık ve siber mağduriyet düzeyleri ise bağımlı değişkenlerdir.

Bağımsız değişkenlere göre oluşan gruplarda bağımlı değişkenler yönünden farklılıklar, grup sayısı iki olan durumlarda bağımsız örneklem $t$ testi yöntemi, ikiden fazla olan gruplarda ise tek yönlü varyans analizi (ANOVA) yöntemi kullanılarak analiz edilmiştir. Her bir analiz yönteminde ön şart olarak gruplar arasındaki varyans farklılıklarının homojenliği Levene testi ile incelenmiştir. Homojenlik şartı sağlanmayan gruplar için ANOVA analizinde Games- Howell analiz yöntemi, homojenlik şartı sağlanan gruplarda ise Tukey testi kullanılmıştır. Bağımlı değişkenler arasındaki ilişkinin şiddeti ve yönünü belirlemek için ise Pearson Korelasyon yöntemi kullanılmıştır.

Siber zorbalık, siber mağduriyet veya yalnızlık algısı düzeylerinde anlamlı bir farklılık oluşan gruplarda etki büyüklüğü değeri eta kare $\left(\mathrm{n}^{2}\right)$ yöntemi kullanılarak hesaplanmıştır. Bu araştırmada bulunan etki büyüklüğü değerlerinin sınıflandırılmasında, Cohen (1988) tarafından verilen $\mathrm{n}^{2}$ değer aralıkları referans alınmıştır. Etki büyüklüğü sınıflandırma sınır değerleri; küçük etki büyüklügü için 0,01, orta etki büyüklügü için 0,06 ve büyük etki büyüklügü̈ için 0,14 olarak kabul edilmiştir (Cohen, 1988).

$\mathrm{Bu}$ araştırma çalışmanın yapıldığı mesleki ve teknik Anadolu lisesinde 2017-2018 eğitim öğretim yılında öğrenim gören 9, 10 ve 11. sınıf öğrencileri ve kullanılan ölçekler ile sınırlıdır. Verilerin analizi için IBM SPSS Statistics 20 programı kullanılmıştır.

\section{Bulgular}

Katılımcıların kişisel bilgi formundan elde edilen verilerin frekans dağılımları incelendiğinde katılımcıların \%84,7'si erkek öğrencilerden, \%15,3'ü ise kız öğrencilerden oluşmaktadır. Katılımcıların $\% 37,4^{\prime}$ ü 11. sinıfta, $\% 36,3^{\prime}$ ü 9. sinıfta ve $\% 26,3^{\prime}$ ü ise 10. sinıfta eğitim görmektedirler. Katılımciların $\% 9,2$ 'si en az bir defa sınıf tekrarı yapmıştır.

Katılımcıların eğitim aldıkları alanların frekans dağılımları; elektrik elektronik teknolojileri için $\% 18,2$, makine teknolojisi için \%11,5, metal teknolojileri için $\% 9,9$, bilişim teknolojileri için $\% 9,5$, biyomedikal cihaz teknolojileri için \%8 ve mobilya-iç mekan tasarımı için \%7,6 olarak belirlenmiştir.

Kardeşi olduğunu beyan eden katılımcıları oranı \%87'dir. Katılımcıların \%15,3'ünün ailesinin aylık geliri 1500TL altında, \%40,1'inin 1500TL-2500TL arasinda, \%28,6'sinın 2500TL-3500TL arasinda ve \%16'sının da 3500TL ve üstüdür. Katılımcıların \%91,2'sinin anne babası birlikte yaşamaktadır. Katılıcımların anne eğitim seviyelerinin frekans dağılımları; ortaokul için \%35, ilkokul için \%34, lise için \%30,2 ve yüksekokul/üniversite için $\% 5,3$ olarak bulunmuştur. Katılımcıların baba eğitim seviyelerinin frekans dağılımları; lise için \%34,4, ilkokul için \%29, ortaokul için \%27,1 ve yüksekokul/üniversite için $\% 8,8$ olarak bulunmuştur. 
Evde internet erişimi olan katılımcıların oranı \%78,2' dir. Katılımcıların \%92,4'ü en az bir sosyal medya uygulamasını aktif olarak kullanmakta ve \%90,8'i akıllı cep telefonu kullanmaktadır. Sosyal medyayı arkadaşları ve aile bireyleri ile iletişimde olmak için kullanan katılımcıların oranı \%48,9, düşüncelerini daha çok kişiye ulaştırmak için kullanan katılımcıların oranı $\% 20,2$, aynı düşünce ve hobiye sahip bir grupla paylaşımda bulunmak için kullanan katılımcıların oranı $\% 16$, yaşam tarzının ve düşüncelerinin beğenilmesi için kullanan katılımcıların oranı \%7,6, anonim bir kimlik altında düşüncelerini ifade etmek için kullanan katılımcıların oranı $\% 4,6$ ve belirli bir yaşam tarzında profil oluşturmak için kullanan katılımcıların oranı \%2,7 olarak dağılım göstermiştir.

Katılımcların \%61'i internete cep telefonundan, \%37'si kişisel bilgisayarından ve \%1,9'u ise internet cafeden bağlanmaktadır. Katılımcıların internete bağlanma sürelerine bakıldığında günde 6 saatten fazla bağlananların oranı \%32,4, günde 1-3 saat arasında bağlananların oranı \%26,3, günde 3-6 saat arasında bağlananların oranı \%22,9, haftada 1-3 defa bağlananların oranı $\% 8,8$ ve günde 1 saatten az bağlananların oranı \%9,5 olarak bulunmuştur. İnterneti sosyal medya için kullanan katılımcıların oranı \%49,6, oyun oynamak için kullanan katılımcıların oranı \%28,2, ödev yapmak için kullanan katılımcların oranı $\% 10,7$, film ve dizi izlemek için kullanan katılımcıların oranı $\% 8$ ve haberleri takip etmek kullanan katılımcıların oranı \%3,4'dür.

\section{Siber Zorbalık, Siber Mağduriyet ve Yalnızlık Algısı Arasındaki İlişkiye Yönelik Bulgular}

Çalışmada bağımlı değişkenlerin arasındaki ilişkinin şiddeti ve yönünü tespit etmek için çift yönlü Pearson Korelasyon analizi yapılmıştır. Siber zorbalık düzeyi ile siber mağduriyet düzeyi $(\mathrm{p}<0,01$, $\mathrm{r}=0,532, \mathrm{~N}=262$ ) ve siber zorbalık düzeyi ile yalnızlık algısı arasında pozitif yönde ( $<<0,01, r=0,236$, $\mathrm{N}=262$ ) anlamlı bir ilişki olduğu tespit edilmiştir. Siber mağduriyet ve yalnızlık algısı arasında ise anlamlı bir ilişki tespit edilememiştir ( $\mathrm{p}>0,01, \mathrm{r}=0,118, \mathrm{~N}=262)$.

\section{Cinsiyete Göre Oluşan Gruplarda Siber Zorbalık, Siber Mağduriyet ve Yalnızlık Algısı Düzeylerine İlişkin Bulgular}

Katılımcıların cinsiyetine göre oluşan gruplarda siber zorbalık, siber mağduriyet ve yalnızlık algısı düzeylerinin anlamlı bir farklılık gösterip göstermediği bağımsız örneklem t testi ile incelenmiştir. Cinsiyete göre oluşan gruplar arasında bağımlı değişkenler yönünden anlamlı bir farklılık olmadığı görülmüştür ( $p>0,05$, tYalnzllk Algısı $=0,006$, tsiber Zorbalk $=-1,293$, tsiber Mağduriyet $=-1,822)$.

\section{Sınıf Tekrarına Göre Oluşan Gruplarda Siber Zorbalık, Siber Mağduriyet ve Yalnızlık} Algısı Düzeylerine İlişkin Bulgular

Sınıf tekrarı değişkenine göre oluşan gruplarda yalnızlık algısı $(p>0,05, t=0,645)$ ve siber mağduriyet düzeyi algısı ( $p>0,05, \mathrm{t}=0,901)$ anlamlı bir farklılık göstermezken, siber zorbalık düzeyinde ise zayıf da olsa anlamlı bir farklılıktan bahsedilebilir ( $p=0,054, t=2,021)$. Sınıf tekrarı yapanların siber zorbalık puanlarının ortalaması $(\bar{X}=37,5)$, hiç sınıf tekrarı yapmamış öğrencilere göre $(\bar{X}=30,94)$ yüksektir.

\section{Ebeveynlerin Birliktelik Durumlarına ve Kardeşin Olup Olmamasına Göre Oluşan Gruplarda Siber Zorbalık, Siber Mağduriyet ve Yalnızlık Algısı Düzeylerine İlişkin Bulgular}

Anne ve babanın birlikteliklerine göre oluşan gruplarda siber zorbalık, siber mağduriyet ve yalnızlık algısı düzeylerinde anlamlı bir farklılık oluşmamıştır ( $p>0,05$, tyalızlık Algııı $=-1,644$, tsiber Zorbalık $=-$ 0,161, tsiber Mağduriyet =-1,041). Katılımcıların kardeşlerinin olup olmamasına göre oluşan gruplarda da 
bağımlı değişkenler yönünden anlamlı bir farklılık olmadığı tespit edilmiştir ( $p>0,05$, tralızılık Algıı =- 0,384 , tSiber Zorbalık=-0,079, tSiber Mağduriyet =-1,021).

\section{Anne ve Babanın Eğitim Durumlarına Göre Oluşan Gruplarda Siber Zorbalık, Siber Mağduriyet ve Yalnızlık Algısı Düzeylerine İlişkin Bulgular}

Babanın eğitim seviyesine göre oluşan gruplarda bağımlı değişkenler yönünden anlamlı bir farklılık tespit edilmemiştir ( $>0,05)$. Annenin eğitim seviyesine göre oluşan gruplarda bağımlı değişkenler yönünden anlamlı bir farklılık olup olmadığı grup sayısı ikiden fazla olduğu için ANOVA analiziyle incelenmiştir. Bağımlı değişkenlerin homojen dağılımı gerçekleşmediği için gruplar arası anlamlı farklılığın incelenmesinde Post-Hoc analiz yöntemlerinden Games-Howell yöntemi kullanılmıştır. Tablo 2'den görüleceği gibi annesi ilkokul mezunu olan grubun siber zorbalık puan ortalaması $(\overline{\mathrm{X}}=28,84)$, annesi lise mezunu olan grubun ortalamasindan $(\overline{\mathrm{X}}=33,27)$ anlamlı derecede düşüktür $(p=0,042)$. Etki düzeyi değeri ise 0,03 olarak bulunmuştur.

Tablo 2. Siber Mağduriyet Düzeyinin Annenin Eğitim Durumu Değişkenine Göre Oluşan Gruplardaki Games-Howell Analiz Bulguları

\begin{tabular}{|c|c|c|c|c|c|}
\hline Bağımlı Değişken & $\begin{array}{c}\text { (I) Annenin Eğitim } \\
\text { Durumu ve Puan } \\
\text { Ortalaması }(\overline{\mathrm{X}})\end{array}$ & $\begin{array}{l}\text { (J) Annenin Eğitim Durumu } \\
\text { ve Puan Ortalaması }(\bar{X})\end{array}$ & $\begin{array}{c}\text { Ortalama Farkı } \\
\text { (I-J) }\end{array}$ & Std. Hata & $p$ \\
\hline \multirow{3}{*}{$\begin{array}{l}\text { Siber Zorbalık } \\
\text { Düzeyi }\end{array}$} & \multirow{3}{*}{$\begin{array}{l}\text { İlkokul } \\
(\overline{\mathrm{X}}=28,84)\end{array}$} & Ortaokul $(\overline{\mathrm{X}}=31,83)$ & $-2,99480$ & 1,72171 & 0,307 \\
\hline & & Lise $(\bar{X}=33,27)$ & $-4,43578^{*}$ & 1,66364 & 0,042 \\
\hline & & $\begin{array}{c}\text { Yüksekokul / Üniversite } \\
(\overline{\mathrm{X}}=37,28)\end{array}$ & $-8,44302$ & 3,51316 & 0,119 \\
\hline
\end{tabular}

Annenin eğitim durumuna göre oluşan gruplarda siber mağduriyet ve yalnızlık algısı yönünden ise anlamlı bir farklılık tespit edilmemiştir $(p>0,05)$.

\section{Ailenin Aylık Gelir Durumuna Göre Oluşan Gruplarda Siber Zorbalık, Siber Mağduriyet ve Yalnızlık Algısı Düzeylerine İlişkin Bulgular}

Ailenin aylık gelir durumuna göre oluşan bağımsız gruplarda yalnızlık algısı yönünden anlamlı bir farklılık oluşmadığı görülmüş̧ür $(p>0,05)$. Siber zorbalık ve siber mağduriyet düzeylerinde

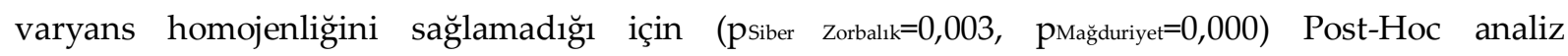
yöntemlerinden Games-Howell yöntemi kullanılmıştır. Siber zorbalık düzeyi için ailenin aylık gelir durumu grupları arasında anlamlı bir farklılık olmadığı tespit edilmiştir ( $>>0,05)$.

Tablo 3. Siber Mağduriyet Düzeyinin Aylık Gelir Değişkenine Göre Oluşan Gruplardaki Games-

Howell Analiz Bulguları

\begin{tabular}{|c|c|c|c|c|c|}
\hline $\begin{array}{l}\text { Bağımlı } \\
\text { Değişken }\end{array}$ & $\begin{array}{l}\text { (I) Ailenin Aylık Toplam } \\
\text { Geliri ve Puan } \\
\text { Ortalaması }(\overline{\mathrm{X}})\end{array}$ & $\begin{array}{l}\text { (J) Ailenin aylık toplam } \\
\text { geliri ve Puan Ortalaması }(\bar{X})\end{array}$ & $\begin{array}{l}\text { Ortalama } \\
\text { Fark1 (I-J) }\end{array}$ & Std. Hata & $p$ \\
\hline \multirow{3}{*}{$\begin{array}{c}\text { Siber } \\
\text { Mağduriyet } \\
\text { Düzeyi }\end{array}$} & \multirow{3}{*}{1500 TL altında $(\bar{X}=26,42)$} & $\begin{array}{c}1500 \mathrm{TL}-2500 \mathrm{TL} \text { arasinda } \\
(\overline{\mathrm{X}}=28,30)\end{array}$ & $-1,87976$ & 0,85564 & 0,130 \\
\hline & & $\begin{array}{l}2500 \text { TL ve } 3500 \text { TL arasinda } \\
\qquad(\overline{\mathbf{X}}=29,74)\end{array}$ & $-3,32167^{*}$ & 1,06808 & 0,013 \\
\hline & & 3500 TL üzerinde $(\bar{X}=30,66)$ & $-4,24167^{*}$ & 1,35740 & 0,014 \\
\hline
\end{tabular}

Sonuçlar siber mağduriyet düzeyi açısından değerlendirildiğinde; ailesinin aylık geliri $1500 \mathrm{TL}$ altında olan grubun siber mağduriyet puanlarının ortalaması $(\overline{\mathrm{X}}=26,42)$, aylık geliri 2500 TL-3500TL $(\overline{\mathrm{X}}=29,74)$ arasında olanlardan ve 3500TL üstü $(\overline{\mathrm{X}}=30,66)$ olanlardan anlamlı derecede düşüktür ( $\mathrm{p}_{3500 T L}$ ve üstü=0,014, p2500-3500тL=0,013) (bkz. Tablo 3). Etki değeri büyüklüğü 0,03 olarak bulunmuştur. 


\section{Sınıf Düzeyi ile Eğitim Görülen Bölüme Göre Oluşan Gruplarda Siber Zorbalık, Siber Mağduriyet ve Yalnızlık Algısı Düzeylerine İlişkin Bulgular}

Sınıf düzeyine göre oluşan gruplarda yalnızlık algısı yönünden anlamlı bir farklılık görülmemiştir ( $p>0,05)$. Sınıf düzeyine göre oluşan gruplarda siber zorbalık ve siber mağduriyet düzeylerine ilişkin analiz bulguları Tablo 4'te verilmiştir.

Tablo 4. Siber Mağduriyet ve Siber Zorbalık Düzeyinin Sınıf Düzeyi Değişkenine Göre Oluşan Gruplardaki Games-Howell Analiz Bulguları

\begin{tabular}{|c|c|c|c|c|c|}
\hline Bağımlı Değişken & $\begin{array}{l}\text { (I) Sınıf Düzeyi ve } \\
\text { Puan Ortalaması }(\bar{X})\end{array}$ & (J) Sınıf Düzeyi & $\begin{array}{c}\text { Ortalama Farkı } \\
\text { (I-J) }\end{array}$ & Std. Hata & $p$ \\
\hline \multirow{6}{*}{$\begin{array}{l}\text { Siber Zorbalık } \\
\text { Düzeyi }\end{array}$} & \multirow[t]{2}{*}{ 9. Sinuf $(\bar{X}=29,03)$} & 10. Sinuf & $-1,85248$ & 1,66317 & 0,507 \\
\hline & & 11. Sinif & $-5,41740^{*}$ & 1,64498 & 0,003 \\
\hline & \multirow[t]{2}{*}{ 10. $\operatorname{Sinif}(\bar{X}=30,88)$} & 9. Sinuf & 1,85248 & 1,66317 & 0,507 \\
\hline & & 11. Sinif & $-3,56492$ & 1,85812 & 0,137 \\
\hline & \multirow[t]{2}{*}{ 11. Sinif $(\bar{X}=34,44)$} & 9. Sinif & $5,41740^{*}$ & 1,64498 & 0,003 \\
\hline & & 10. Sinif & 3,56492 & 1,85812 & 0,137 \\
\hline \multirow{6}{*}{$\begin{array}{c}\text { Siber Mağduriyet } \\
\text { Düzeyi }\end{array}$} & \multirow{2}{*}{ 9. Sinıf $(\bar{X}=27,51)$} & 10. Sinif & $-0,74508$ & 0,87223 & 0,670 \\
\hline & & 11. Sinif & $-2,93319^{*}$ & 0,99466 & 0,010 \\
\hline & \multirow{2}{*}{ 10. Sinif $(\bar{X}=28,26)$} & 9. Sinif & 0,74508 & 0,87223 & 0,670 \\
\hline & & 11. Sinif & $-2,18811$ & 1,10750 & 0,121 \\
\hline & \multirow{2}{*}{ 11. Sinıf $(\bar{X}=30,44)$} & 9. Sinif & $2,93319^{*}$ & 0,99466 & 0,010 \\
\hline & & 10. Sinif & 2,18811 & 1,10750 & 0,121 \\
\hline
\end{tabular}

Siber zorbalık ve siber mağduriyet puanları ise Tablo 4'de görüldüğü üzere 9. ve 11. sınıf düzeyi gruplarında anlamlı bir farklılık göstermiştir. Buna göre 9. sınıfların oluşturduğu grubun siber zorbalık puan ortalaması $(\overline{\mathrm{X}}=29,03)$, 11. sinıfların puan ortalamasından $(\overline{\mathrm{X}}=34,44)$ anlamlı derecede düşüktür $(\mathrm{p}=0,003)$. 11. sinıflardan oluşan grubun siber mağduriyet puan ortalaması $(\overline{\mathrm{X}}=30,44)$, 9. sinıfların puan ortalamasından $(\overline{\mathrm{x}}=27,51)$ anlamlı derecede yüksektir $(\mathrm{p}=0,010)$. Etki büyüklüğü değeri siber zorbalık düzeyi için 0,04 , siber mağduriyet düzeyi için ise 0,03 olarak bulunmuştur.

Eğitim görülen bölüme göre oluşan gruplarda ise yalnızlık algısı yönünden anlamlı bir farklılık tespit edilmemiştir $(p>0,05)$. Siber zorbalık ve siber mağduriyet düzeylerinde ise bölümlere göre anlamlı bir farklılık olup olmadığı Games-Howell analizi ile incelenmiştir. Bulgular Tablo 5'te verilmiştir.

Tablo 5. Siber Mağduriyet ve Siber Zorbalık Düzeyinin Bölüm Değişkenine Göre Oluşan Gruplardaki Games-Howell Analiz Bulguları

\begin{tabular}{|c|c|c|c|c|c|}
\hline $\begin{array}{c}\text { Bağımlı } \\
\text { Değişken }\end{array}$ & $\begin{array}{l}\text { (I) Bölüm ve Puan } \\
\text { Ortalaması }(\bar{X})\end{array}$ & (J) Bölüm ve Puan Ortalaması ( $\bar{X})$ & $\begin{array}{c}\text { Ortalama Farkı } \\
\text { (I-J) }\end{array}$ & Std. Hata & $p$ \\
\hline \multirow{5}{*}{$\begin{array}{c}\text { Siber Zorbalık } \\
\text { Düzeyi }\end{array}$} & \multirow{5}{*}{$\begin{array}{l}\text { Bilişim Teknolojileri } \\
(\overline{\mathrm{X}}=27,56)\end{array}$} & Biyomedikal Cihaz Tek. $(\overline{\mathrm{X}}=31,95)$ & $-4,39238$ & 2,74706 & 0,605 \\
\hline & & Elektrik-Elektronik Tek. $(\overline{\mathrm{X}}=34,18)$ & $-6,62750$ & 2,44477 & 0,086 \\
\hline & & Metal Teknolojisi $(\overline{\mathbf{X}}=33,30)$ & $-5,74769$ & 2,66729 & 0,282 \\
\hline & & Makine Teknolojisi $(\overline{\mathrm{X}}=39,46)$ & $-11,90667^{*}$ & 2,65704 & 0,001 \\
\hline & & Mobilya ve İç Mekân $(\bar{X}=30,25)$ & $-2,69000$ & 3,08140 & 0,950 \\
\hline \multirow{5}{*}{$\begin{array}{c}\text { Siber } \\
\text { Mağduriyet } \\
\text { Düzeyi }\end{array}$} & \multirow{5}{*}{$\begin{array}{l}\text { Makine Teknolojisi } \\
\qquad(\overline{\mathrm{X}}=35,16)\end{array}$} & Bilişim Teknolojileri $(\bar{X}=27,96)$ & $7,20667^{*}$ & 2,28319 & 0,032 \\
\hline & & Biyomedikal Cihaz Tek. $(\overline{\mathrm{X}}=30,14)$ & 5,02381 & 2,79759 & 0,478 \\
\hline & & Elektrik-Elektronik Tek. $(\overline{\mathrm{X}}=27,29)$ & $7,87500^{*}$ & 2,06689 & 0,007 \\
\hline & & Metal Teknolojisi $(\overline{\mathrm{X}}=28,26)$ & $6,89744^{*}$ & 2,26760 & 0,043 \\
\hline & & Mobilya ve İç Mekân $(\bar{X}=29,95)$ & 5,21667 & 2,64316 & 0,372 \\
\hline
\end{tabular}

Tablo 5'den görüldüğü üzere makine teknolojileri bölümünde okuyanların oluşturduğu grubun siber zorbalık puanlarının ortalaması $(\bar{X}=39,46)$, bilişim teknolojileri bölümünde okuyanların 
oluşturduğu grubun puan ortalamasından $(\overline{\mathrm{x}}=27,56)$ anlamlı derecede yüksektir $(\mathrm{p}=0,001)$. Makine teknolojileri bölümünün siber mağduriyet puanları ortalaması $(\overline{\mathrm{X}}=35,16)$, bilişim teknolojileri $(\overline{\mathrm{X}}=27,96$, $\mathrm{p}=0,032)$, elektrik elektronik teknolojileri $(\overline{\mathrm{X}}=27,29 \mathrm{p}=.007)$ ve metal teknolojilerinin puan ortalamasından $(\bar{X}=28,26, p=0,043)$ anlamlı derecede yüksek çıkmıştır. Etki büyüklüğü değeri siber zorbalık düzeyi için 0,08 , siber mağduriyet düzeyi için ise 0,13 olarak bulunmuştır.

\section{İnternet Kullanım Alışkanlıklarına Göre Oluşan Gruplarda Siber Zorbalık, Siber Mağduriyet ve Yalnızlık Algısı Düzeylerine İlişkin Bulgular}

İnternete bağlanılan ortama göre oluşan gruplar arasında bağımlı değişkenler yönünden anlamlı bir farklılık bulunmamıştır ( $p>0,05)$.

Tablo 6. Siber Zorbalık Düzeyinin Internete En Çok Bağlanma Amacı Değişkenine Göre Oluşan Gruplardaki Games-Howell Analiz Bulguları

\begin{tabular}{|c|c|c|c|c|c|}
\hline Bağımlı Değişken & $\begin{array}{l}\text { (I) İnternete En } \\
\text { Çok Bağlantı } \\
\text { Amacı ve Puan } \\
\text { Ortalaması }(\bar{X})\end{array}$ & $\begin{array}{c}\text { (J) İnternete En Çok Bağlantı } \\
\text { Amacı ve Puan } \\
\text { Ortalaması }(\overline{\mathrm{X}})\end{array}$ & $\begin{array}{c}\text { Ortalama Fark1 } \\
\text { (I-J) }\end{array}$ & Std. Hata & $p$ \\
\hline \multirow{4}{*}{$\begin{array}{l}\text { Siber Zorbalık } \\
\text { Düzeyi }\end{array}$} & \multirow{4}{*}{$\begin{array}{l}\text { Sosyal medyayı } \\
\text { kullanmak } \\
(\overline{\mathbf{X}}=32,46)\end{array}$} & Oyun oynamak $(\overline{\mathrm{X}}=30,09)$ & 2,36694 & 1,49950 & 0,513 \\
\hline & & $\begin{array}{c}\text { Ödev ve derslerle ilgili } \\
\text { araştırma yapmak }(\overline{\mathrm{X}}=26,67)\end{array}$ & $5,78297^{*}$ & 1,73687 & 0,013 \\
\hline & & $\begin{array}{c}\text { Film veya dizi izlemek, } \\
\text { indirmek }(\bar{X}=36,38)\end{array}$ & $-3,91941$ & 4,14050 & 0,876 \\
\hline & & $\begin{array}{l}\text { Haberleri ve gündemi takip } \\
\text { etmek }(\bar{X}=34,11)\end{array}$ & $-1,64957$ & 4,68320 & 0,996 \\
\hline
\end{tabular}

Tablo 6'dan görüldüğü üzere internete bağlanma amacına göre oluşan gruplarda yalnızlık alg1sı düzeyi ile siber mağduriyet düzeyi yönünden anlamlı bir farklılık olmadığı tespit edilmiştir ( $p>0,05)$. Siber zorbalık düzeyinde ise internet bağlantı amaçları en çok sosyal medya olan grubun siber zorbalık puan ortalaması ( $\overline{\mathrm{X}}=32,46)$, internete en çok ödev ve derslerle ilgili araştırma yapmak için bağlanan grubun puan ortalamasından $(\overline{\mathrm{x}}=26,67)$ anlamlı olarak yüksek çıkmıştır $(\mathrm{p}=0,013)$. Etki büyüklüğü 0,04 olarak bulunmuştur.

İnternete bağlanma sıklı̆̆ına göre oluşan gruplarda bağımlı değişkenlerin anlamlı bir fark oluşturup oluşturmadıkları incelendiğinde, siber mağduriyet ve yalnızlık algısı yönünden herhangi bir fark oluşmadığı tespit edilmiştir ( $p>0,05)$.

Tablo 7. Siber Zorbalık Düzeyinin Internete Bağlanma Sıklığına Göre Games-Howell Analiz Bulguları

\begin{tabular}{|c|c|c|c|c|c|}
\hline $\begin{array}{l}\text { Bağımlı } \\
\text { Değişken }\end{array}$ & $\begin{array}{c}\text { (I) İnternete bağlanma } \\
\text { sıklığı Puan } \\
\text { Ortalaması }(\bar{X})\end{array}$ & $\begin{array}{c}\text { (J) İnternete bağlanma Sıklığı Puan } \\
\text { Ortalaması }(\bar{X})\end{array}$ & $\begin{array}{l}\text { Ortalama } \\
\text { Farki (I-J) }\end{array}$ & Std. Hata & $p$ \\
\hline \multirow{4}{*}{$\begin{array}{l}\text { Siber Zorbalık } \\
\text { Düzeyi }\end{array}$} & \multirow{4}{*}{$\begin{array}{l}\text { Günde } 1 \text { saatten az } \\
\qquad(\bar{X}=27,44)\end{array}$} & Haftada $1-3$ defa $(\bar{X}=36,69)$ & $-9,25565$ & 3,54564 & 0,094 \\
\hline & & Günde $1-3$ saat $(\overline{\mathrm{X}}=30,55)$ & $-3,11072$ & 1,95107 & 0,506 \\
\hline & & Günde 3-6 saat $(\overline{\mathrm{X}}=30,48)$ & $-3,04333$ & 2,09474 & 0,596 \\
\hline & & Günde 6 saatten fazla $(\overline{\mathrm{X}}=32,91)$ & $-5,47765^{*}$ & 1,83186 & 0,032 \\
\hline
\end{tabular}

İnternete günde 6 saatten fazla bağlanan grubun siber zorbalık puan ortalaması $(\bar{x}=32,91)$, günde 1 saatten az bağlanan grubun puan ortalamasından $(\bar{X}=27,44)$ anlamlı derecede yüksek çıkmıştır $(p=0,032)$ (bkz. Tablo 7). Etki büyüklüğü siber zorbalık düzeyi için 0,03 olarak bulunmuştur.

Evde internet bağlantısının olup olmamasına göre oluşan gruplarda bağımlı değişkenler yönünden anlamlı bir farklılık bulunmamıştır ( $p>0,05)$. Cep telefonun akıllı özellikte olup olmamasına 
göre oluşan gruplarda siber zorbalık düzeyi anlamlı bir farklılık göstermezken siber mağduriyet ve yalnızlık algısı düzeyleri anlamlı farklıklar göstermiştir.

Tablo 8. Bağımlı Değişkenlerin Cep Telefonunun Akıllı Olması Değişkenine Göre Oluşan Gruplardaki Bağımsız Örneklem t Testi Bulguları

\begin{tabular}{|c|c|c|c|c|c|c|c|c|}
\hline \multirow[b]{2}{*}{$\begin{array}{c}\text { Bağımlı } \\
\text { Değişkenler }\end{array}$} & \multirow[b]{2}{*}{ 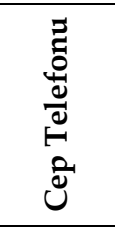 } & \multirow[b]{2}{*}{$\mathbf{Z}$} & \multirow[b]{2}{*}{ 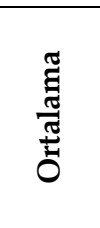 } & \multirow[b]{2}{*}{ 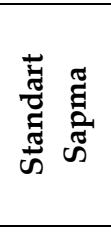 } & \multicolumn{4}{|c|}{ Homojenlik Testi ve t Testi Bulguları } \\
\hline & & & & & $\begin{array}{l}\text { Levene } \\
\text { Testi } \\
\text { Sig.(p) }\end{array}$ & $\begin{array}{c}\text { Varyansların } \\
\text { Eşit Olduğu } \\
\text { Varsayımı } \\
(p<0.05)\end{array}$ & $t$ değeri & $p$ \\
\hline \multirow{2}{*}{$\begin{array}{l}\text { Yalnızlık } \\
\text { Algisı }\end{array}$} & Evet & 238 & 39,25 & 9,29 & 0,044 & Geçerli & $-2,873$ & 0,004 \\
\hline & Hayır & 24 & 44,87 & 7,37 & & Geçerli Değil & $-3,468$ & 0,002 \\
\hline \multirow{2}{*}{$\begin{array}{c}\text { Siber } \\
\text { Mağduriyet }\end{array}$} & Evet & 238 & 28,99 & 6,96 & 0,036 & Geçerli & 1,403 & 0,162 \\
\hline & Hayır & 24 & 26,95 & 4,34 & & Geçerli Değil & 2,046 & 0,048 \\
\hline \multirow{2}{*}{$\begin{array}{c}\text { Siber } \\
\text { Zorbalık }\end{array}$} & Evet & 238 & 31,62 & 11,54 & 0,975 & Geçerli & 0,335 & 0,738 \\
\hline & Hayır & 24 & 30,79 & 11,83 & & Geçerli Değil & 0,328 & 0,745 \\
\hline
\end{tabular}

Tablo 8'de görüleceği üzere cep telefonu akıllı özellikte olmayan grubun yalnızlık algısı puan ortalaması $(\overline{\mathrm{X}}=44,87)$, akıllı cep telefonu kullanan grubun yalnızlık algısı puan ortalamasından $(\overline{\mathrm{X}}=39,25)$ anlamlı olarak yüksek çıkmıştır ( $\mathrm{p}=0,002, \mathrm{t}=-3,468)$. Akıllı telefon kullanmayan grubun siber mağduriyet puan ortalaması $(\bar{x}=26,95)$, akıllı cep telefonu kullanan grubun puan ortalamasina $(\bar{x}=28,99)$ göre anlamlı olarak daha düşüktür $(\mathrm{p}=0,048, \mathrm{t}=2,046)$. Etki büyüklüğü yalnızlık algısı için ve siber mağduriyet düzeyleri için 0,02 olarak bulunmuştır.

\section{Sosyal Medya Kullanım Durumu ve Alışkanlıklarına Göre Oluşan Gruplarda Siber Zorbalık, Siber Mağduriyet ve Yalnızlık Algısı Düzeylerine İlişkin Bulgular}

Sosyal medya hesabı olan ve olmayanlar arasında yalnızlık algısı yönünden anlamlı bir farklılık bulunmamıştır $(p>0,05)$. Sosyal medyayı kullanma amacına göre oluşan gruplarda ise bağımlı değişkenler yönünden anlamlı bir farklılık görülmemiştir ( $p>0,05)$.

Tablo 9. Bağımlı Değişkenlerin Sosyal Medya Kullanılması Değişkenine Göre Oluşan Gruplardaki Bağımsız Örneklem t Testi Bulguları

\begin{tabular}{|c|c|c|c|c|c|c|c|c|}
\hline \multirow[b]{2}{*}{$\begin{array}{c}\text { Bağımlı } \\
\text { Değişkenler }\end{array}$} & \multirow[b]{2}{*}{ 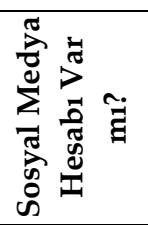 } & \multirow[b]{2}{*}{ z } & \multirow[b]{2}{*}{ 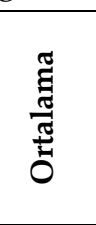 } & \multirow[b]{2}{*}{ 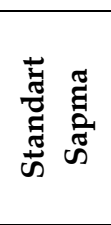 } & \multicolumn{4}{|c|}{ Homojenlik Testi ve t Testi Bulguları } \\
\hline & & & & & $\begin{array}{l}\text { Levene } \\
\text { Testi }(p)\end{array}$ & $\begin{array}{c}\text { Varyansların } \\
\text { Eşit Olduğu } \\
\text { Varsayımı } \\
(\mathrm{p}<0.05)\end{array}$ & $t$ değeri & $p$ \\
\hline \multirow{2}{*}{$\begin{array}{c}\text { Yalnızlık } \\
\text { Algısı }\end{array}$} & Evet & 242 & 39,65 & 9,37 & 0,138 & Geçerli & $-0,694$ & 0,488 \\
\hline & Hayır & 20 & 41,15 & 7,82 & & Geçerli Değil & $-0,809$ & 0,427 \\
\hline \multirow{2}{*}{$\begin{array}{c}\text { Siber } \\
\text { Mağduriyet }\end{array}$} & Evet & 242 & 29,06 & 6,96 & 0,002 & Geçerli & 2,145 & 0,033 \\
\hline & Hayır & 20 & 25,70 & 2,69 & & Geçerli Değil & 4,482 & 0,000 \\
\hline \multirow{2}{*}{$\begin{array}{c}\text { Siber } \\
\text { Zorbalık }\end{array}$} & Evet & 242 & 31,88 & 11,72 & 0,031 & Geçerli & 1,676 & 0,095 \\
\hline & Hayır & 20 & 27,40 & 8,324 & & Geçerli Değil & 2,235 & 0,034 \\
\hline
\end{tabular}

Sosyal medya hesabı olup olmamasına göre oluşan gruplar, siber mağduriyet ve siber zorbalık düzeyleri açısından incelendiğinde, sosyal medya hesabı olanların siber mağduriyet puan ortalamaları $(\overline{\mathrm{X}}=29,06)$, sosyal medya kullanmayanlara göre $(\overline{\mathrm{X}}=25,70)$ anlamlı derecede yüksektir (bkz. Tablo 9) $(\mathrm{p}=0,000, \mathrm{t}=4,482)$. Tablo 9'dan görüleceği üzere siber zorbalık düzeyi bakımından sosyal medya hesabı olanların siber zorbalık puan ortalamaları $(\overline{\mathrm{X}}=31,88)$ sosyal medya hesabı olmayanlara göre $(\overline{\mathrm{X}}=27,40)$ 
anlamlı derecede yüksek çıkmıştır ( $\mathrm{p}=0,034, \mathrm{t}=2,235)$. Etki büyüklüğü siber zorbalık ve siber mağduriyet düzeyleri için 0,01 olarak bulunmuştur.

\section{Yalnızlık Algısı, Siber Zorbalık ve Siber Mağduriyet Puanlarına İlişkin Betimleyici İstatistik Bulguları}

Tablo 10'da çalışmada kullanılan ölçeklerden elde edilen bağımlı değişkenlere ilişkin puanların betimleyici istatistik bulguları verilmiştir.

Tablo 10. Bağımlı Değişkenlere Ilişkin Betimleyici Istatistik Bulguları

\begin{tabular}{cccc}
\hline & Yalnızlık Algısı & Siber Mağduriyet & Siber Zorbalık \\
\hline Ortalama & 39,7672 & 28,8092 & 31,5458 \\
\hline Medyan & 40,0000 & 26,0000 & 25,0000 \\
\hline Standart Sapma & 9,26469 & 6,79149 & 11,55347 \\
\hline Minimum Değer & 20,00 & 24,00 & 24,00 \\
\hline Maksimum Değer & 65,00 & 48,00 & 85,00 \\
\hline
\end{tabular}

Çalışmada elde edilen bulgular incelendiğinde Yalnızlık Algısı Ölçeği puan ortalaması 39,76 (N=262), Siber Mağduriyet Ölçeği'nin puan ortalaması 28,80 ve Siber Zorbalık Ölçeği'nin puan ortalaması ise 31,54 olarak bulunmuştur (bkz. Tablo 10).

\section{Tartışma ve Sonuç}

Veri analizi sonucunda elde edilen bulgulara göre araştırma soruları şu şekilde cevaplandırılmıştır.

- Ergenlerde yalnızlık algısı ile siber zorbalık arasında arasında anlamlı bir ilişki var mıdır?

Ergenlerde yalnızlık algısı ve siber zorbalık düzeyi arasında pozitif yönde anlamlı bir ilişki bulunmuştur. Fakat bu ilişkinin kuvvetli bir ilişki olduğu söylenemez (r=0,236). Özel (2013), çalışmasında siber zorbalığın depresyonla ilişkili olduğunu göstermiştir. Yalnızlık algısının da depresyonla ilişkili olduğunu gösteren çalışmalar literatürde mevuttur (K1lınç ve Sevim, 2005). Yalnızlık algısının sonucu olarak depresyonda bulunan bireyler, siber zorbalık davranışları sergileyebilir. Siber zorbalığın öfke biçimi olarak kabul edilmesi durumunda bireyler kontrol edemedikleri öfke patlamaları sonucu ilişkilerinin bozulmasıyla birlikte yalnızlık durumuyla karşılaşabilirler (Haskan-Avcı ve Yıldırım, 2014).

- Ergenlerde yalnızlık algısı ile siber mağduriyet arasında anlamlı bir ilişki var mıdır?

Yalnızlık algısı düzeyi ile siber mağduriyet düzeyi arasında anlamlı bir ilişki bulunmamıştır $(\mathrm{p}>0,01, \mathrm{r}=0,118)$.

- Ergenlerde siber zorbalık ve siber mağduriyet arasında anlamlı bir ilişki var mıdır?

Ergenlerde siber zorbalık düzeyi ile siber mağduriyet arasında orta şiddette pozitif yönde anlamlı bir ilişki bulunmuştur $(\mathrm{r}=0,532)$. Siber zorbalık davranışına maruz kalan bireyler intikam duygusuyla hareket ederek bu tip davranışlar sergileyebilirler (Akça, 2016). Bu sebeple siber mağduriyet düzeyinin artışı ile birlikte siber zorbalık düzeyi de artabilir. Aynı şekilde siber zorbalık davranışı sergileyen bireylerin, intikam duygusuyla hareket eden mağdurların zorba davranışlarına maruz kalmaları sonucu mağduriyet düzeylerinde artış görülebilir. Bu görüşle bağlantılı olarak Usta (2013), çalışmasında siber mağduriyet ile siber zorba olma düzeyleri arasında anlamlı bir korelasyon olduğunu belirtmiştir. 
- Ergenlerin cinsiyetine, ebeveynlerinin birliktelik durumuna, kardeşin olup olmamasına, anne-babanın eğitim seviyesine ve ailenin aylık gelir durumuna göre oluşan gruplarda siber zorbalık, siber mağduriyet ve yalnızlık algısı anlamlı yönde farklılaşmakta mıdır?

Kızlar ve erkekler arasında siber zorbalık, siber mağduriyet ve yalnızlık algısı düzeyi yönünden anlamlı bir farklılık bulunmamıştır. Türkiye'de yapılan araştırmalar siber zorbalık davranışlarına erkeklerde daha sık rastlanıldığını ortaya koymuştur (Baykal, 2016; Eroğlu vd., 2015; Süslü, 2016; Yaman ve Sönmez, 2015; Usta, 2013). Kowalski ve Limber (2013), siber zorbalığın olumsuz sonuçlarının geleneksel zorbalığa benzer şekilde erkekler için daha belirgin olduğunu ifade etmişlerdir. Özel (2013), çalışmasında siber mağduriyet açısından cinsiyete göre anlamlı bir farklılaşma olmadığını göstermiştir.

Anne babanın birliktelik durumu ile ergenin kardeş sahibi olma durumunun siber zorbalık, siber mağduriyet ve yalnızlık algısı düzeyleri açısından anlamlı bir farklılığa yol açmadığı görülmüştür. Anne babanın birlikte yaşaması durumunun siber zorbalık ve siber mağduriyet düzeylerinde anlamlı bir farklllık göstermediği Baykal (2016) tarafından da tespit edilmiştir.

Babanın eğitim seviyesi siber zorbalık, siber mağduriyet ve yalnızlık algısı düzeyi yönünden anlamlı bir farklılık oluşturmazken, annesi lise mezunu olanlar, annesi ilk okul mezunu olanlara göre daha fazla siber zorbalık davranışlarında bulunmuşlardır. Bu durum annenin eğitim seviyesinin artmasına paralel olarak ailenin ekonomik refah düzeyinin iyileşmesi sonucu bireyin bilişim teknolojisi araçlarına daha kolay erişebilmesiyle açıklanabilir. Annenin eğitim düzeyinin incelendiği araştırmalarda annenin eğitim düzeyinin artmasıyla birlikte siber zorbalık davranışlarının azaldığını belirten araştırmaların yanında arttığını gösteren araştırmalar da mevcuttur (Baykal, 2016; Eroğlu vd., 2015).

Ailesinin aylık geliri 1500TL ve altında olanlar, ailesinin aylık geliri 2500TL ve üzerinde olanlardan daha az siber zorbalıkla karşılaşmışlardır. Ailenin ekonomik gücü azaldıkça bilişim cihazlarına ve internete erişim güçleşir. Bu sebeple daha düşük gelir gruplarında siber zorbalıkla karşılaşma ihtimali azalabilir. Baykal (2016) çalışmasında aylık geliri 3000TL ve üzeri olanların daha fazla siber zorbalığa maruz kaldığını ortaya koymuştur. Ailesinin aylık geliri 2000TL altında olanların daha çok siber zorbalık davranışları yaptığını gösteren araştırmalar da mevcuttur. Ailesinin aylık geliri düşük olan bireylerin daha az siber zorbalıkla karşılaşması ya da daha az siber zorbalık yapmasının bilişim teknolojileri cihazlarına ve internete olan erişim zorluğundan kaynaklandığını süren araştırmaların yanında siber zorbalığın ailenin aylık geliriyle ilgisinin olmadığını belirten araştırmalarda mevcuttur (Eroğlu vd., 2015).

- Ergenlerin sınıf tekrarı yapıp yapmamalarına, eğitim aldıkları sınıf seviyesine ve eğitim gördükleri mesleki bölüme göre oluşan gruplarda siber zorbalık, siber mağduriyet ve yalnızlık algısı anlamlı yönde farklılaşmakta mıdır?

11. sınıf öğrencileri, 9. sınıf öğrencilerine göre daha fazla siber zorbalık davranışında bulunurken aynı zamanda daha fazla siber zorbalık davranışlarına da maruz kalmışlardır. 11.sınıf öğrencilerinin ergenlik dönemi özellikleri ile ilişkili olarak 9. sınıf öğrencilerine göre daha çok kendini beğendirme, saygı görme, popülerlik kazanma gibi duygular taşıyabilir. Bu duygular sonucu olarak 11. sınıf öğrencilerinin siber zorbalık davranışlarına daha çok yöneldiği düşünülebilir. Sınıf tekrarı yapan öğrencilerin siber zorbalık puan ortalamaları, sınıf tekrarı yapmayan öğrencilerin puan ortalamalarından yüksek çıkmıştır. Yaman ve Sönmez (2015) çalışmalarında sınıf düzeyine göre siber zorbalığın anlamlı bir farklılık göstermediğini belirtmişlerdir. Benzer şekilde Baykal (2016), sınıf düzeyine göre siber zorbalık ve mağduriyetin anlamlı farklılık göstermediğini belirtmiştir. 
Makine teknolojileri öğrencilerinin siber zorbalık puan ortalamaları, sadece bilişim teknolojileri öğrencilerinden anlamlı derecede yüksek çıkmıştır. Makine teknolojileri öğrencilerinin siber mağduriyet puan ortalamaları ise bilişim teknolojileri, metal teknolojileri ve elektrik elektronik teknolojileri öğrencilerinin puan ortalamalarından daha yüksektir. Siber zorbalık ve siber mağduriyet arasındaki pozitif korelasyon bu sonucu açılayabilir. Siber zorbalık seviyesinin yüksekliğiyle birlikte siber mağduriyet seviyesi de yükselmiştir.

- Ergenlerin akıllı telefon sahibi olup olmadıklarına, internet kullanma amaçlarına, internet kullanım sürelerine, internete nereden bağlandıklarına, sosyal medya kullanıp kullanmamalarına ve sosyal medyayı kullanma amaçlarına göre oluşan gruplarda siber zorbalık, siber mağduriyet ve yalnızlık algısı anlamlı yönde farklılaşmakta mıdır?

İnternete günde 6 saatten fazla bağlananlar, günde 1 saatten az bağlananlara göre daha fazla siber zorbalık davranışlarında bulunmuşlardır. Literatürdeki benzer çalışmalarda da internet kullanım süresi yüksek olanların siber zorbalık ve siber mağduriyet düzeylerinin diğer gruplara göre daha yüksek olduğu tespit edilmiştir (Baykal, 2016; Doğan vd., 2009; Eroğlu vd., 2015; Ünver, 2016). Literatürde internet bağımlılı̆̆ının depresyon, yalnızlık ve sosyal destek gibi değişkenlerle ilişkili olduğunu gösteren çalışmalar mevcuttur (Esen, 2010). Bu sonuç, yeterli sosyal destek göremeyen bireylerin internette daha çok vakit geçirdiğini buna bağlı olarak da sosyal destek eksikliğinden kaynaklanan yalnızlık algısına bağlı olarak siber zorbalık davranışları göstermesiyle açıklanabilir.

İnternete en çok sosyal medya uygulamalarına erişmek için bağlananların siber zorbalık seviyeleri, interneti en çok ödev ve ders araştırmaları için kullananlara göre daha yüksektir. Literatürde interneti en çok çevrimiçi oyun oynamak için kullanma durumunun siber zorbalık ve mağduriyet ile ilişkili olduğunu belirten çalışmalar mevcuttur (Eroğlu vd., 2015). Ünver (2016), çalışmasında ödev sitelerini takip edenlerin siber zorbalık puanlarının, sosyal medya sitelerini takip edenlere göre daha düşük olduğunu belirtmiştir.

Sosyal medya hesabı olanlar daha fazla siber zorbalığa maruz kalırken aynı zamanda daha fazla siber zorbalık davranışı sergilemektedirler. Sosyal medyayı kullanma amaçlarına göre ise herhangi bir farklılık tespit edilmemiştir. Sosyal medya uygulamalarında geçirilen sürenin artması, bireyler arasındaki etkileşimin de artması demektir. Bu sebeple ilişkilerde meydana gelen çatışmalar, siber zorbalık olarak dışa vurulabilir. Sosyal medyada anonim bir kimliğe bürünmenin vermiş olduğu cesaret ve güven duyguları da siber zorbalığı kolaylaştırıcı etmenler olarak açıklanabilir.

İnternete bağlanılan yer açısından siber zorbalık, siber mağduriyet ve yalnızlık algısı düzeylerinde anlamlı bir farklılık oluşmamıştır. Literatürde internet kafeye gidenler ile siber zorbalık ve mağduriyet arasında ilişki olduğunu gösteren çalışmalar mevcuttur (Eroğlu vd., 2015). Süslü (2016), çalışmasında siber zorbalık yönünden internete bağlanılan yerin anlamlı bir farklılık oluşturmadığını söylemiştir. Bu sonuç günümüzde internet bağlantısının artık çoğunlukla akıllı cep telefonları üzerinden yapılmasıyla açılanabilir.

Akıllı cep telefonu kullanmayanlar, akıllı cep telefonu kullananlara göre kendilerini daha yalnız hissetmelerine rağmen daha az siber zorbalığa maruz kalmışlardır. Akıllı cep telefonu kullanmayanlar sosyal medya uygulamaları ve diğer etkileşimli ortamlardan daha uzak kalmaktadırlar. Bu da siber mağduriyet puanlarının düşüklüğünü açıklayabilir. Akıllı cep telefonu kullanmayanların sosyal medya uygulamalarından uzak kalmaları sonucu arkadaşlarıyla olan paylaşımlarının sadece yüz yüze vakit geçirilen zamanla sınırlı kaldığı göz önüne alındığında bu bireylerin yalnız hissettikleri düşünülebilir. 


\section{Öneriler}

Siber mağduriyet, davranışın türüne ve yayılma etkisine göre ciddi sonuçları olabilen bir durumdur. Siber zorbalığa uğramış ve siber zorbalığın etkisi altında olan mağdurlar korku, toplum baskısı, tehdit, şantaj gibi sebeplerle yardım istemekten kaçınabilirler. Bu bireyler intikam duygusuyla siber zorbalık davranışları sergileyebilirler. Siber zorbalık davranışı gösteren ergenlerde, siber zorbalık ve yalnızlık arasındaki pozitif ilişki göz önüne alınarak davranışın temelinde yalnızlık algısının olup olmadığı incelenmelidir. Yalnızlık algısı gözlemlenen ergenlerde de bu durumun sebebinin siber zorbalıktan kaynaklanıp kaynaklanmadığı tespit edilmelidir. Böyle bir durumda bireyde yalnızlığa yol açan siber zorbalık davranışının kaynağı tespit edilerek; bireyde yalnızlığın getireceği psikolojik ve fizyolojik problemler önlenebilir.

Öğretmenlere ve velilere siber zorbalık ve siber mağduriyet hakkında bilgilendirici seminerler verilerek durum tespiti yapabilmeleri sağlanmalıdır. Öğrenciler, siber zorbalığın üstesinden gelebilecekleri yöntemler ve yasal hakları konusunda bilgilendirilmelidir. İzleyen çalışmalarda örnekleme farklı okul türleri de dahil edilerek daha geniş bir örneklem oluşturulabilir. Ayrıca velilerin, siber zorbalık ve mağduriyet farkındalıklarının incelenmesi de literatürde yapılacak benzer çalışmalar için önerilir.

\section{Kaynaklar}

Akça, A. (2016). Lise öğrencilerinde siber zorbahı̆a maruz kalma durumlarının, etkileyen faktörlerin ve etkilerinin incelenmesi. Yüksek Lisans Tezi. Koç Üniversitesi Sağllk Bilimleri Enstitüsü, İstanbul.

Arıcak, O., Kınay, H. ve Tanrıkulu, T. (2012). Siber Zorbalık Ölçeği'nin ilk psikometrik bulguları. HAYEF Journal of Education, 9(1), 101-114.

Arıcak, O., Kınay, H. ve Tanrıkulu, T. (2012). Siber Mağduriyet Ölçeği'nin ilk psikometrik bulguları. Akdeniz Eğitim Araştırmaları Dergisi, 11, 1-6.

Atli, A., Keldal, G. ve Sonar, O. (2015). Üniversite öğrencilerinin yabancılaşma ile yalnızlık düzeyleri arasındaki ilişki. Mustafa Kemal Üniversitesi Sosyal Bilimler Enstitüsü Dergisi, 12(29), 149-160.

Ayas, T. ve Horzum, M. B. (2010). Sanal zorba/kurban ölçek geliştirme çalışması. Akademik Bakış Dergisi, 19, 1-15.

Ayas, T. ve Horzum, M. B. (2012). İlköğretim öğrencilerinin sanal zorba ve mağdur olma durumu. İlköğretim Online, 11(2), 369-380.

Bahar, H. H. ve Meral, D. (2016). Ortaöğretim öğrencilerinde problemli internet kullanımının yalnızlık ve psikolojik iyi oluş ile ilişkisinin incelenmesi. Erzincan Üniversitesi Eğitim Fakültesi Dergisi, 18(2), 1117-1134.

Baş, T. (2013). Anket. Ankara: Seçkin.

Başol, G. (2008). Bilimsel araştırma yöntemleri. İstanbul: Lisans.

Baştürk-Akca, E., Sayımer, İ. ve Ergül, S. (2015). Ortaokul öğrencilerinin sosyal medya kullanımları ve siber zorbalık deneyimleri: Ankara örneği. Global Media Journal, 5(10), 71-86.

Baykal, F. (2016). Lise öğrencilerinde siber zorbalı ve mağduriyetin ailedeki koruyucu etmenlerle ilişkisi: Afyonkarahisar ili örneği. Yüksek Lisans Tezi. Afyon Kocatepe Üniversitesi Sosyal Bilimler Enstitüsü, Afyonkarahisar. 
Cohen, J. (1988). Statistical Power Analysis for the Behavioral Sciences (2. basım). Hillsdale, NJ: Lawrence Erlbaum.

Demir, A. (1989). U.C.L.A. Yalnızlık Ölçeği'nin geçerlik ve güvenilirliği. Psikoloji Dergisi, 7(28), 14-18.

Doğan, T., Çetin, B. ve Sungur, M. Z. (2009). İş Yaşamında Yalnızlık Ölçeği Türkçe formunun geçerlilik ve güvenilirlik çalışması. Anadolu Psikiyatri Dergisi, 10(271), 271-277.

Eroğlu, T., Aktepe, E., Akbaba, S., Işık, A. ve Özkorumak, E. (2015). Siber zorbalık ve mağduriyetin yaygınlığının ve risk faktörlerinin incelenmesi. Eğitim ve Bilim, 40(177), 93-107.

Esen, E. (2010). Ergenlerde internet bağımlılığını yordayan psiko-sosyal değiş̧kenlerin incelenmesi. Yüksek Lisans Tezi. Dokuz Eylül Üniversitesi Eğitim Bilimleri Enstitüsü, İzmir.

Gencer, H. (2017). Ortaokul öğrencilerinde internet bağımlılığı ve siber zorbalık davranışları ile ilişkili değişkenlerin incelenmesi. Yüksek Lisans Tezi. Cumhuriyet Üniversitesi Eğitim Bilimleri Enstitüsü, Sivas.

George, D. ve Mallery, M. (2010). SPSS for Windows Step by Step: A Simple Guide and Reference, 17.0 update (10. b.). Boston: Pearson.

Gezgin, M. D. ve Çuhadar, C. (2012). Bilgisayar ve öğretim teknolojileri eğitimi bölümü öğrencilerinin siber zorbalığa ilişkin duyarlılık düzeylerinin incelenmesi. Eğitim Bilimleri Araştırmaları Dergisi, 2(2), 93-104.

Haskan-Avcı, Ö. ve Yıldırım, İ. (2014). Ergenlerde şiddet eğilimi, yalnızlık ve sosyal destek. Hacettepe Üniversitesi Ĕ̆itim Fakültesi Dergisi, 29(1), 157-168.

Hudson, D. B., Elek, S. M. ve Campbell-Grossman, C. (2000). Depression, self-esteem, loneliness, and social support among adolescent mothers participating in the new parents project. Adolescence, 35(139), 445-453.

Kavuk, M. ve Keser, H. (2016). İlköğretim okullarında siber zorbalık. Hacettepe Üniversitesi Ĕ̆itim Fakültesi Dergisi, 31(3), 520-535.

Kılınç, H. ve Sevim, S. A. (2005). Ergenlerde yalnızlık ve bilişsel çarpıtmalar. Ankara Üniversitesi Ĕ̆itim Bilimleri Fakültesi Dergisi, 38(2), 67-89.

Kılınç, S. (2012). Örnek büyüklüğü, güç kavramları ve örnek büyüklüğü hesaplaması. Journal of Mood Disorders, 2(3), 140-142.

Kim, J., LaRose, R. ve Peng, W. (2009). Loneliness as the cause and the effect of problematic internet use: The relationship between Internet use and psychological well-being. Cyberpsychology \& Behavior: The Impact of the Internet, Multimedia and Virtual Reality on Behavior and Society, 12(4), 451-455. https://doi.org/10.1089/cpb.2008.0327

Kowalski, R. M. ve Limber, S. P. (2013). Psychological, physical, and academic correlates of cyberbullying and traditional bullying. The Journal of Adolescent Health: Official Publication of the Society for Adolescent Medicine, 53(1 Suppl), 13-20. http://dx.doi.org/10.1016/j.jadohealth. 2012.09.018

Li, Q. (2005, Nisan). Cyber-bullying in schools: The nature extent of adolescents' experience. American Education Research Association (AERA) Conference'da sunulmuş bildiri. Montreal, Quebec, Canada. 
Li, Q. (2006). Cyberbullying in schools: A research of gender differences. School Psychology International, 27(2), 157-170.

Özdemir, M. ve Akar, F. (2011). Lise öğrencilerinin siber-zorbalığa ilişkin görüşlerinin bazı değişkenler bakımından incelenmesi. Kuram ve Uygulamada Eğitim Yönetimi, 4(4), 605-626. https://dergipark.org.tr/tr/pub/kuey/issue/10326/126601 sayfasından erişilmiştir.

Özel, S. (2013). Lise öğrencileri arasında siber zorbalık, siber mă̆duriyet, depresyon ve benlik saygısı ilişkisi. Yüksek Lisans Tezi. Fatih Üniversitesi Sosyal Bilimler Enstitüsü, İstanbul.

Patchin, J. W. ve Hinduja, S. (2006). Bullies move beyond the schoolyard: A preliminary look at cyberbullying. Youth Violence and Juvenile Justice, 4(2), 148-169.

Peker, A. (2015). Ergenlerin saldırganlık ve siber zorbalık davranışları arasındaki ilişkilerin incelenmesi. EKEV Akademi Dergisi, 61, 323-336.

Peker, A., Özhan, M. B. ve Eroğlu, Y. (2015). Ergenlere yönelik siber zorbalıkla başa çıma ölçeğinin geliştirilmesi. International Journal of Human Sciences, 12(1), 569-581.

Pişkin, M. (2002). Okul zorbalığı: tanımı, türleri, ilişkili olduğu faktörler ve alınabilecek önlemler. Kuram ve Uygulamada Ĕ̆itim Bilimleri, 2(2) ,531-562.

Semerci, A. (2017). Lise öğrencilerinin siber zorbalık ve mağduriyet durumlarının farklı değişkenler açısından incelenmesi. Kastamonu Ĕ̆gitim Dergisi, 25(4), 1285-1300.

Serin, H. (2012). Ergenlerde siber zorbalık / siber mağduriyet yaşantıları ve bu davranışlara ilişkin öğretmen ve eğitim yöneticilerinin görüşleri. Doktora Tezi. İstanbul Üniversitesi Sosyal Bilimler Enstitüsü, İstanbul.

Süslü, P.D. (2016). Lise öğrencilerinde siber zorbalık ve siber mağduriyetin benlik saygıs, anne, baba ve akran ilişkileri açısından incelenmesi. Doktora Tezi. Maltepe Üniversitesi Sosyal Bilimler Enstitüsü, İstanbul.

Şahin, M., Sarı, S. V., Özer, Ö. ve Er, S. H. (2010). Lise öğrencilerinin siber zorba davranışlarda bulunma ve maruz kalma durumlarına ilişkin görüşleri. Süleyman Demirel Üniversitesi Fen-Edebiyat Fakültesi Sosyal Bilimler Dergisi, 2010(21), 257-270. https://dergipark.org.tr/tr/pub/sufesosbil/issue/11416/136365 sayfasından erişilmiştir.

Tanrıkulu, T., Kınay, H. ve Arıcak, O. (2013). Siber zorbalığa ilişkin duyarlılık ölçeği: Geçerlik ve güvenirlik çalışması. Trakya Üniversitesi Eğitim Fakültesi Dergisi, 3(1), 38-47.

TÜİK. (2013). 06-15 Yaş grubu çocuklarda bilişim teknolojileri kullanımı ve medya. http://www.tuik.gov.tr/PreHaberBultenleri.do?id=15866 sayfasından erişilmiştir.

TÜIKK. (2016). Hanehalkı bilişim teknolojileri kullanım araştırması. http://www.tuik.gov.tr/PreHaberBultenleri.do?id=21779 sayfasından erişilmiştir.

TÜiK. (2017). Hanehalkı bilişim teknolojileri kullanım araştırması. http://www.tuik.gov.tr/HbPrint.do?id=24862 sayfasından erişilmiştir.

Türk Dil Kurumu. (2011). Türkçe sözlük. Ankara: TDK.

Usta, A. (2013). Lise öğrencilerinin öfke düzeyleri ile siber zorbalı düzeyleri arasındaki ilişkinin incelenmesi (Samsun ili örneği). Yüksek Lisans Tezi. Ondokuz Mayıs Üniversitesi Eğitim Bilimleri Enstitüsü, Samsun. 
Ünver, H. (2016). Siber zorbalık ile problemli internet kullanımı ve riskli internet davranışı arasındaki ilişki ve bu değişkenlerin çeşitli demografik özellikler açısından incelenmesi. Yüksek Lisans Tezi. Gazi Üniversitesi Eğitim Bilimleri Enstitüsü, Ankara.

We Are Social. (2017). Digital in 2017: Global Overview. https://wearesocial.com/special-reports/digitalin-2017-global-overview sayfasından erişilmiştir.

Yaman, E. ve Sönmez, Z. (2015). Ergenlerin siber zorbalık eğilimleri. Online Journal of Technology Addiction \& Cyberbullying, 2(1), 18-31.

Yenilmez, Y. ve Seferoğlu, S. S. (2013). Sanal zorbalık ve öğretmenlerin farkındalık durumlarına bir bakış. Eğitim ve Bilim, 38(169), 420-432.

\section{Yazarların Katkı Oranı Beyanı}

Çalışma sürecinin araştırma modeline uygun olarak planlanması Mehmet İbrahim Talan sorumluluğunda, örneklem üzerinde verilerin toplanması ve analiz işlemleri Gülnihal Bostan ve Yağmur Öztürk sorumluluğunda gerçekleştirilmiştir. Yazarlar araştırmanın makale formatında hazırlanmasında ortak sorumluluk üstlenmişlerdir.

\section{Destek ve Teșekkürr Beyanı}

$\mathrm{Bu}$ araştırmada herhangi bir kurum, kuruluş ya da kişiden destek alınmamıştır.

\section{Çatışma Beyanı}

Araştırma ile ilgili diğer kişi ve kurumlarla herhangi bir kişisel ve finansal çıkar çatışması yoktur.

\section{Etik Bildirim}

Bu araştırma, 01.01.2020 tarihinden önce yapıldığından etik kurul kararı zorunluluğu yoktur. 